Federal Reserve Bank of Dallas

Globalization and Monetary Policy Institute

Working Paper No. 68

http://www.dallasfed.org/assets/documents/institute/wpapers/2011/0068.pdf

\title{
Exchange Rate Pass-Through, Domestic Competition and Inflation: Evidence from the 2005/08 Revaluation of the Renminbi ${ }^{*}$
}

\author{
Raphael Auer \\ Swiss National Bank
}

January 2011

\begin{abstract}
How important is the effect of exchange rate fluctuations on the competitive environment faced by domestic firms and the prices they charge? To answer this question, this paper examines the $17 \%$ appreciation of the yuan against the US dollar from 2005 to 2008 . In a monthly panel covering 110 sectors, a 1\% appreciation of the Yuan increases US import prices by roughly $0.8 \%$. It is then shown that import prices, in turn, pass through into producer prices at an average rate of roughly 0.7 , implying that a $1 \%$ Yuan appreciation increases the average US producer price of tradable goods by $0.8 \% * 0.7=0.56 \%$. In contrast, exchange rate movements of other trade partners have much smaller effects on import prices and hardly any effect on producer prices. The paper next demonstrates that the pass through response into import prices is heterogeneous across sectors with different characteristics such as traded-input intensity or the shape of demand for the sector's goods. In contrast, the rate at which import prices pass through into domestic producer prices is found to be homogenous across the sectors. Finally, the insights of the analysis are employed to simulate the inflationary effect of a Yuan revaluation. For example, the relative price shock caused by a 25\% appreciation of the Yuan spread evenly over 10 months is equivalent to a temporary increase of the US PPI inflation rate by over five percentage points. Because such an appreciation would also influence the overall skewness of the distribution of price changes at the sectoral level, it would likely also impact U.S. equilibrium inflation.
\end{abstract}

JEL codes: F11, F12, F14, F15, F16, F40, E31, L16

\footnotetext{
* Raphael Auer, Swiss National Bank, Börsenstr. 15, P.O. Box Ch-8022, Zürich, Switzerland. + 41-44-631-38-84. raphael.auer@snb.ch. I thank Jean Imbs for comments. The views expressed in this paper are those of the author and do not necessarily reflect the views of the Swiss National Bank, the Federal Reserve Bank of Dallas or the Federal Reserve System.
} 


\section{Introduction}

The topic of China's exchange rate policy against the US dollar is currently the "most salient of controversies in international monetary economics" (see Frankel (2010)) and there are not many signs that the discussion will go away any time soon. US policy makers have repeatedly demanded that China revalue its currency by $20 \%$ to $40 \%$ (see for example Geithner (2009)), demands that have consistently been rebuked by Chinese government officials.

While a discussion of the Chinese exchange rate policy seems justified given the magnitude of the US-Chinese trade imbalance, it is striking that the inflationary effect of an appreciation of the Renminbi (yuan in what follows below) has not entered the policy discussion at all. The rise of cheap imports from China was a major contributing fact to the low-inflation environment during the last decade (see IMF (2008), Auer and Fischer (2010), Bugamelli et al. (2009), and Auer et al.(2010)). If economic policies such as a yuan appreciation are successful in reducing global "imbalances", also the disinflationary effect of cheap Chinese imports will at least partly be reversed.

Indeed, the sheer volume of imports from China suggests that the inflationary effect of a yuan revaluation cannot be negligible: last year, Chinese exports to the US were worth over 300 billion USD, implying that nearly a sixth of all US consumption of manufactured goods is actually made in China (see Rynn (2005)). What would happen to US inflation if firms producing one in six goods in the US consumer's shopping basket - and virtually all clothing, toys, or consumer electronics, not to mention the shopping basket itself - suddenly face $20 \%$ to $40 \%$ higher labor costs? Such an event would have a substantial impulse on inflation due to the weight of Chinese goods in the US inflation index; more importantly, it also seems likely that such a dramatic shock might alter the equilibrium prices in many industries altogether, leading to widespread inflationary dynamics.

This paper quantifies the indirect inflationary effect of a yuan appreciation on the competitive environment in US producer markets. It does so by studying the $17 \%$ appreciation of the yuan against the US dollar during 2005 and 2008. The analysis examines how the appreciation passed through into US import prices and, in turn, how these import prices then affected US producer prices. The first part of this exercise is motivated by the recent advances studying the microeconomic determinants of exchange rate pass through into import prices ${ }^{1}$ and the literature quantifying how exchange rate movements pass through into aggregate prices. $^{2}$

\footnotetext{
${ }^{1}$ Early studies focused mostly on exchange rate pass through in the car industry (Knetter (1989 and 1993) and Goldberg and Verboven (2001 and 2005), see later also the work of Hellerstein (2008) and Nakamura and Zerom (2010) for the case of the beer and coffee industries respectively). More recent studies establish pass through rates in datasets spanning many industries (see Gopinath and Rigobon (2006), Gopinath and Itskhoki (2010a and b), and Gopinath et al. (2010)).

${ }^{2}$ See, among many others, Yang (1997), Giovannini (1988), Froot and Klemperer (1989), Devereux and Engel (2002), Corsetti et al. (2004), Jeannine and Fujiisee (2004), Campa and Goldberg (2005), Atkeson and Burstein (2009), Auer and Chaney (2007 and 2009) and Goldberg and Campa (2010). Also see Goldberg and M. Knetter (1997) for a survey of earlier analysis in the area of exchange rate pass through.
} 
The principal difference between this study and the existing literature is its focus on domestic prices. In the analysis below, the principal dependent variable of interest are US producer prices, measured as "prices received by domestic producers for their output" (see BLS (2010), emphasis added). China is the world's largest exporter and if the yuan appreciates, this affects the equilibrium prices that US producers charge. In this paper, I set out to quantify the latter indirect effect of exchange rate changes on domestic price setting.

In this sense, the empirical exercises most closely related to this study is not the literature on exchange rate pass through, but the work of Chen et al. (2009) and Auer and Fischer (2010), who analyze how long-run changes in import competition affect the "toughness" of competition and the prices of domestic firms. Here, I do not analyze the long run effect of increasing trade integration, but the short run dimension of how fluctuations of the exchange rate affect the competitive environment. ${ }^{3}$

The second difference of this study compared to the existing literature is the origin of the exchange rate shocks. The yuan appreciations originated from policy decisions rather than from market movements. There are strong reasons to believe that such policy decisions are affected differently by macroeconomic shocks in the US or China than market movements of the exchange rates would be (as there would be no reason to intervene if the market-determined and the policy-desired exchange rates coincided).

Given that the origin of the shocks that caused the yuan to appreciate during 2005 to 2008 are different from market-determined exchange rate movements, there are strong reasons to believe that also the rate of pass through following these appreciation differs from the rate of pass through following market-determined exchange rate movements. ${ }^{4} \mathrm{In}$ particular, during 2005 to 2008, Chinese policy makers a attached a substantial weight on the euro when setting their exchange rate (see Frankel and Wei (2008 and 2009) and Frankel (2009)). This peg led to a mechanical relation between the euro/dollar and yuan/dollar exchanges rate that causes cost shocks for Chinese exporters to the US.

Pass through might also be different for the case of the yuan revaluation compared to other currency movements since the path of the yuan was predictably going in one direction only (as forward contracts from the 2005 to 2008 period reveal). Thus, while a exporter from a country with a freely floating rate might only have responded to large shocks (since exchange rate volatility reduces incentives to adjust prices due to the implicit option value of waiting to see how the exchange rate evolves), Chinese exporters could predict that every appreciation was permanent and likely to be succeeded by future appreciations. ${ }^{5}$

\footnotetext{
${ }^{3}$ Chen at al. (2009) also build a strong theoretical foundation of why and how imports affect the general toughness of competition and the prices of domestic firms. The latter work uses the preferences developed by Ottaviano et al. (2001) and Melitz and Ottaviano (2005) to model price complementarities. A second theoretical approach taken by Gust et al. (2010) builds on the strategic price complementarily modeled in Kimbal (1995) and Dotsey and King (2005) to analyze the pricing response of domestic and foreign firms to exchange rate shocks. See also Guerrieri et al. (2010).

${ }^{4}$ Burstein et al. (2003 and 2005) study pass through following large depreciations such as the one following the Argentinean Debt crisis, also with the prior that the rate of pass through could be very different following a crisis than following day-to-day exchange rate movements during calm market times.

${ }^{5}$ Froot and Klemperer (1989) show that 'temporary' exchange rate changes may not pass-through to import prices, while Baum et al. (2001) demonstrate that imperfect information on the permanent com-
} 
Last, one could also expect the rate of pass through for China to differ from the one for the rest of the world since sectors are heterogeneous in the rate of pass through and the composition of Chinese exports differs starkly from that of other nations. ${ }^{6}$

Indeed, I find marked differences in the empirical estimates when comparing pass through following the yuan appreciation to pass through when other currencies move.

The first step of the analysis of this paper examines the pass-through rate into imports prices, finding that within the traded goods sector, the yuan exchange rate passes through into import prices at an average rate of 0.8. In contrast, the rate of pass through of other exchange rate movements (the rest of the world (ROW) exchange rate, which is a trade-weighted exchange rate average of all currencies except the yuan) is estimated below 0.3 .

The second step analyzes the extent to which the exchange rate affects US producers prices. A $1 \%$ yuan appreciation increases the US producer prices of traded goods by $0.55 \%$ and - since traded goods have a weight in the PPI index of about $30 \%$ - the US PPI index by $0.165 \%$. Again, this is in stark contrast to the rate at which other exchange rates pass through into producer prices: there is no evidence that the trade-weighted ROW exchange rate passes through in producer prices at short horizons and, while it does pass through in the long run, it does so at a rate of less than 0.1 .

In addition to analyzing the link between the exchange rate and producer prices directly, I also investigate the indirect link between import prices and producer prices in Two-Stage Least Square (2SLS) specifications that first analyze the impact of the exchange rate on import prices and thereafter the effect of import prices on producer prices. I find that import prices pass through into producer prices of traded goods at an average rate of roughly 0.7 , implying that the $0.8 \%$ increase of import prices associated with a $1 \%$ yuan appreciation, in turn, increases US producer prices of tradable goods by roughly $0.7 * 0.8 \%=0.56 \% .{ }^{7}$

The third step investigates whether pass through is heterogeneous across sectors. I repeat both the reduced form estimations and 2SLS specifications, spliting the sample up by sector characteristics such as labor intensity of production, traded input intensity, the shape of demand for the sectors' goods, and general trade openness. ${ }^{8}$ In reduced form estimations, there are large differences in the rate at which the exchange rate passes through

ponent of changes in the exchange rate affect the relationship between the exchange rate volatility, prices, and profitability. Also Taylor's (2000) analysis of the degree of pass through depending on the inflationary environment makes a case for the importance of firm's expectation about the future evolution of desired prices when responding to exchange rate changes.

${ }^{6}$ Goldberg and Tille (2008) and Gopinath et al. (2010a) demonstrate that the denomination of imports is of major consequences for the rate of pass through. Against this backdrop, it might be worthwhile to investigate whether Chinese imports tend to be more often dollar-denominated than imports from other origins.

${ }^{7}$ To the best of the author's knowledge, the study at hand is the first to investigate the extent to which exchange rate induced-import prices movements feed into general producer price inflation.

${ }^{8}$ Bacchetta and Van Wincoop (2003), Burstein et al. (2003), and Goldberg and Campa (2010) make the case that distribution cost intensity plays a major role for the rate of pass through into consumer prices. Because the BLS considers retailing and wholesaling as services that are provided separately from the good itself (see Bureau of Labor Statistics (2010)), producer prices contain a much smaller share of distribution costs than do consumer prices. 
into producer prices.

Next, reproducing the 2 SLS estimations for the various subsamples, I decompose the source of the heterogeneous pass through into producer prices, finding that import prices pass through into producer prices at rates that are rather similar across all sectors, yet that import prices react very heterogeneously to the exchange rate.

The fact that the response of import prices to the exchange rate is heterogeneous across sectors while the consequent response of producer prices to these import price changes is homogenous makes it possible to further test the 2SLS specifications. The latter are implicitly assuming that changes in the yuan exchange rate affect producer prices exclusively via their impact on import prices. To test this assumption, the analysis of section 7 adds interactions of the exchange rate with a sector characteristics to the estimation as additional instruments. As is documented below, the latter interaction-instruments satisfy the exclusion restriction even if the aggregate exchange rate is correlated with US prices for reasons other than the import price channel. Since the interaction instruments are valid also if the latter condition is violated, but the exchange rate is a valid instrument only if it holds, an overidentification test can examine whether this condition is true in the data. Following this approach, the analysis finds absolutely no evidence that the yuan exchange rate changes affect producer prices via any channel other than via import prices.

The forth step of paper investigates the response of the import volume from China to the yuan exchange rate. I find that the volume of imports is quite elastic to exchange rate changes, with a long run (24-36 months after an appreciation) elasticity of import volume to exchange rate changes equal to about -5 . However, the response takes place very slowly, with import volume being nearly unaffected even 16 months after the exchange rate shock.

The fifth and last step of the analysis uses the before-presented findings to answer the following policy question: how sizeable is the relative price shock in terms of the overall US PPI if the yuan were to appreciate strongly? In particular, I investigate the size of the overall shock as a percentage of the PPI if the yuan appreciated by $25 \%$ within 10 months or 25 months. These scenarios, take into account the timing dimension of pass through, the heterogeneous pass-through rates across sectors, and the autoregressive structure of producer and import prices. Once the price response at the sectoral level is estimated, each impact is then multiplied by the sector's weight in the overall PPI, and finally, I sum over all weighted impulses at the sector level to come up with the magnitude of the total shock as a percentage of the overall US PPI.

These simulations reveal that a rapid yuan appreciation would lead to relative price shocks that are economically too large to ignore. For the scenario where the yuan appreciates for 10 months at a rate of $2.5 \%$ per month, the total relative price shock expressed as a percentage of the US PPI inflation rate is predicted well over 5 percentage points. Moreover, the relative price shock caused by the appreciation is also likely to affect U.S. equilibrium inflation since it has a strong influence on the sectoral distribution of price changes: the appreciation would cause a strongly right-skewed distribution of shocks to US producer prices. In the presence of menu costs, the skewness of relative shocks has an effect on equilibrium inflation owing to the asymmetric price responses of firms to small and large shocks (see Ball and Mankiw (1995)). Thus, the simulations suggest that the relative price 
shocks induced by a yuan appreciation may well lead to increasing U.S. inflation.

It is found that at a slower rate of appreciation may be instrumental in containing the effects on US inflation. For the second scenario where the yuan appreciates at $1 \%$ per month for 25 months, the total relative shock expressed in terms of the PPI inflation rate does not exceed 2 percentage points, but is obviously more long-lived and the total relative shock on the US producer price index exceeds 1 percentage point for a period of nearly two years. However, such an apprecation would not affect the distribution of price shocks by much, so that the overall effect on US inflation may be well contained.

Policies that fix the US-Chinese trade balance will inevitably also create large relative price shocks in the US and may well inflate the economy at large. US and Chinese policy makers need to take into account these considerations when deciding on a course of action.

\section{The Yuan and Aggregate US Prices During 2005 to 2008}

Potentially as a reaction to the already then loud criticisms (see Bosworth (2004) and Overholt (2003)) of its policy to keep the yuan fixed at a rate of 8.277 per dollar, Chinese authorities announced in 2005 that they would switch to a new exchange regime in which the yuan is fixed to a basket of currencies.

Since neither the precise basket of currencies nor the underlying weights ever were published, there has been a considerable debate on what currency policy China actually followed during this episode (see Frankel and Wei (2007 and 2008) and Frankel (2009)). While it is thus not precisely known why the Chinese government decided to revalue the yuan from time to time, the unambiguous result is that during 2005 and 2008, the yuan appreciated a combined $17 \%$ against the dollar $(19 \%$ when looking at changes in the natural logarithm).

Figure 1 documents the evolution of the yuan-USD exchange rate (right axis in yuan/USD), the US import prices index of all goods originating from China (left axis), and the US Producer Price Index (PPI, also left axis). The graph starts in December 2003 since the Bureau of Labor Statistics (BLS) reports a separate import price index for goods originating from China starting with that date.

A first salient feature of the data is that the prices of Chinese goods have not kept up with general inflation in the US. While the US PPI index is now well over $20 \%$ higher than in December 2003, the prices of Chinese imports have fluctuated somewhat, but are roughly at their 2003 level.

The second salient feature of the data is that Chinese import prices only trended upward during early 2008, at the same time when the pace of the yuan appreciation was the highest. Also at other times, it seems that the increase in the Chinese import price index tended to be the most positively sloped when the rate of yuan appreciation was the highest.

To consider this relation more closely, Figure 2 relates monthly changes of the exchange rate (a positive value implies a yuan appreciation) to monthly changes in the Chinese import price index. Indeed, there is a strong positive association between the value of the 
yuan and the prices of Chinese goods in the US.

At what average rate of yuan appreciation during end of 2003 to end of 2009 would Chinese import prices have risen at the same rate as the US general producer price index (0.283\% monthly average During 122003 and 12 2009)? A simple regression implies that this would have been the case at an average appreciation rate of $0.69 \%$ per month, as compared to the observed rate of $0.268 \%$. Overall, Figure 2 thus suggests that the Chinese yuan would have had to appreciate a combined 30\% more during 2003 and the end of 2009 so that Chinese goods were equally expensive with US goods as they were in 2003 (of course, the yuan could have been either under or overvalued already then).

Figures 1 and 2 study the relationship between the yuan/dollar exchange rate and Chinese import prices. But how does this exchange rate affect the general US import price level and the prices of US producers? I next answer this questions in a disaggregate analysis at sectoral level.

The reasons for going from an aggregate to a disaggregate analysis threefold. First, since different sectors differ in their characteristics, such analysis can give insights into the microeconomic determinants of pass through rates. Second, (as shown in Section 6 below) pass through is very heterogeneous across different sectors and failure to account for this heterogeneity may lead to an aggregation bias (see Imbs et al. (2005)). Third, as is demonstrated in Section 7, the heterogeneous pass-through rate across sectors can also be employed to further test the proposed methodology.

\section{Data Description}

The analysis of this paper estimates the response of US import and producer prices in a monthly panel dataset spanning the years from December 2003 to December 2009. Trade data by sector and quarter is obtained from the United States International Trade Commission (USITC). The classification of the import data is 6-digit North American Industry Classification System (NAICS) and the selected trade type is the General Customs Value.

Information on import prices is available from the BLS at various levels of aggregation: there are 55 import price indices at the 5-digit level, 64 at the 4-Digit level, and 21 at the 3-digit level. In order to guarantee that all prices used in the analysis below are independent observations, I use the 55 price indices at the 5 -digit level and add to this the 4- or 3-digit prices for which either no 5-digit price is available, or for which I can compute more 5-digit prices from the difference in the import prices index at the 5-digit and 4-digit level taking into account the weight of the 5 digit sectors within the 4-digit sectors. When assigning a 4-digit price to a 5-digit subsector, this is only done once per 4digit sector (randomly selected), so that the prices included in the sample are independent. Information on producer prices is available at the 6- and 5-digit level for all the sectors for which import prices are available.

Last, also sector information such as import or labor intensity, or the sector's general openness to trade is included in the data. Industry is obtained from the Annual Survey of Manufacturers. This restricts the analysis to manufactured goods (NAICS codes 311111 to 339999) since only these sectors are covered in the Annual Survey of Manufacturers. 
The overlap of trade information from the USITC, information from the Annual Survey of Manufacturers, and price information from the BLS yields 110 sectors (at the 5 digit level) when working with import prices, and 320 sectors when working with producer prices.

\section{Exchange Rate Pass Through in Import Prices}

This section investigates the response of import prices indices to the yuan appreciation. It is important to note that this exercise is conceptually different from the analysis undertaken in the recent literature establishing pass through at the goods level (see, for example, Gopinath and Rigobon (2008). Pass through into the import price index has two components. The first effect is the accounting component: if Chinese goods in a certain manufactured goods sector, for example, account for 30\% of the US import price index and pass through at the good level is $80 \%$, by construction pass through into the sector's US import price index is equal to $0.8 * 0.3=24 \%$.

There is, however, a second component working via the toughness of competition in each sector. China is the world's largest exporter and if the yuan appreciates, this affects the equilibrium prices that other countries exporting to the United States charge, leading to an overall pass-through rate of the yuan into the US import price index that can be substantially larger than the accounting component alone. ${ }^{9}$

Table 1 documents that changes of the yuan exchange rate have strong and immediate effects on the US import PPI, whereas changes in other exchange rates are associated with an overall much milder and also more lagged effect on US import prices.

The structure of Table 1 is the following. All columns present the results of fixed effects panel estimations including the 1-month change in the US import PPI index at the 5-digit level of disaggregation as the dependent variable. In Columns (1) to (4), the independent variables include changes in the yuan exchange rate and lags thereof. In Columns (5) to (8), the independent variables include changes in the trade-weighted exchange rate against all currencies other than the yuan and lags thereof. All estimations include a trend and fixed effects.

The difference in the pass-through rate into the US import price index for the yuan and the ROW exchange rate is the starkest in the short run. The specifications of Columns (1) and (5) estimate the pass-through rate into import prices at the 1-month horizon for the yuan (Column (1)) and for other currencies (Column (5)). The 1-month pass-through coefficient is estimated at $46.22 \%$ for the case of China, while it is only estimated at $5.65 \%$ for the ROW exchange rate.

In Columns (2) and (6), I extend the forecasting horizon and include the 1 and 2 month(s) lags of exchange rate changes. For the case of the ROW exchange rate, (see Column (6)), the profile of how exchange rate changes pass through into import prices mirrors that found in earlier research at the good level and is also consistent with the findings of the literature establishing the pass through into aggregate price indices (see,

\footnotetext{
${ }^{9}$ The latter indirect effect on the competitive environment might be especially pronounced for China since it is large, and also, since it is specialized in homogenous goods where small changes in the competitive environment can lead to large differences in equilibrium prices.
} 
for example, Goldberg and Campa (2010)). The pass-through rate is close to 0 in the first month, increases to $8 \%$ after one month, and to a cumulative of $24.3 \%(0.007+0.080+0.156)$ after three months.

In contrast, the rate of pass through of yuan movements into import prices (Column (2)) has a very different profile: the rate of pass through is estimated at $0.28 \%$ after the first month, at $82 \%$ (!!) after two months and at $62.9 \%$ after three months. This difference in the shape of the pass-through (PT) schedule is even more pronounced when evaluating

the 1-year horizon in Columns (3) and (7). For reasons of brevity, instead of adding nine additional one-month lags, three cumulative 3-months lags are added in Column (3) (in essence restricting the PT coefficients to be constant throughout each 3-months interval). Also when autoregressive terms are added to this specification in Columns (4) and (8), the timing of pass through differs starkly when the yuan appreciates as opposed to when the ROW exchange rate moves.

Figure 3 documents the cumulative pass-through rate estimated at various horizons for changes of the yuan (black solid line, surrounded by two dashed lines representing the $95 \%$ Confidence Interval (CI)) and for exchange rate changes of the ROW exchange rate (grey solid line, again surrounded by two dashed lines representing the $95 \% \mathrm{CI}$ ). The pass-through coefficients displayed in this figure are computed following Gopinath et al. (2010b). Each point in Figure 3 presents the rate of pass through resulting from a fixed effects panel regression of "Cumulative Import Price Change over last N Months" as dependent variable on "Cumulative Exchange Rate Change over last N Months" as independent variable, with $\mathrm{N}$ varying from one to 24 .

Table 1 and Figure 3 document that the response of import prices to exchange rate movements is much higher for the yuan than for the rest of the world. Is this a result of the different nature of the exchange rate shocks that drive the yuan as opposed to other exchange rates, or is it simply driven by the different composition of imports from these two regions? Section 6 below deals with the issue of sectoral heterogeneity in detail, but a first gauge at this question is presented in Table 2 .

Table 2 documents that the pass-through rate is higher for the yuan than for the ROW exchange rate in each of the 153 -digit NAICS industries with enough observations making it possible to estimate a separate pass-through regression. The rate of pass through at the 3-months horizon varies substantially across the sectors, but it is true that the passthrough rate is higher for the yuan than for the ROW exchange rate in all 15 sectors. This indicates that it is not the sectoral composition, but rather the source of the exchange rate movements that is behind the high pass-through rate of the yuan. Table 2, however, also emphasizes that the heterogeneity in the rate at which exchange rates pass through into prices is of high economic significance and needs to be addressed when simulating the inflationary impact of a yuan revaluation.

\section{$5 \quad$ Pass Through Into Producer Prices}




\subsection{The Effect of Exchange Rates On US Producer Prices: Reduced- Form Estimations}

This section estimates the pass-through rate of exchange rate fluctuations into the PPI. The BLS defines producer prices as those received by domestic producers for their output. Thus, when evaluating exchange rate pass through into producer prices, the analysis of this paper primarily investigates how domestic US firms respond when the yuan moves. ${ }^{10}$

Figure 4 gives a first overview of whether and to what extent exchange rate changes affect US producer prices. I repeat the exercise presented in Figure 3, but this time with the cumulative change in the sector's US producer price index as dependent variable. The cumulative pass-through rate is estimated at various horizons and for changes of the yuan (black solid line, surrounded by two dashed lines representing the 95\% CI), as well as for exchange rate changes of the ROW exchange rate (grey solid line, surrounded by two dashed lines representing the $95 \% \mathrm{CI}$ ). The pass-through coefficients displayed in this figure are computed in the following way. Consider a pass-through regression with a horizon of $N \epsilon[1,, 2, \ldots, 24]$. Figure 4 presents the rates of pass through resulting from a fixed effects panel regression of "Cumulative Producer Price Change over last N Months" as dependent variable on "Cumulative Exchange Rate Change over last N Months" as independent variable.

Figure 4 documents that yuan changes substantially affect the US domestic prices of traded goods, while there is much weaker pass through of ROW exchange rate changes. Depending on the time horizon, the pass-through rate into producer prices is estimated between 0.38 and 0.62 for the yuan, where the pass-through rate first increases and then decreases with the horizon. In contrast, pass-through of ROW exchange rate movements is small and often insignificant (or even negative and significantly so).

A word of caution is in order: it is premature at this stage of the analysis to conclude that a yuan appreciation has a substantial effect on overall US PPI. The sample includes only manufacturing goods with a weight of slightly less than $30 \%$ in the PPI index. Additionally, these pass-through coefficients only reflect the unweighted average pass-through rate. Chinese exports might be concentrated in sectors with low pass-through rates, so that the average weighted pass-through rate could be very different from the results presented in Figure 4. The analysis deals with this issue below. Before that, however, it is noteworthy to point out the precise mechanism through which the exchange rate affects producer prices.

\subsection{From Import Prices to Producer Prices}

The above analysis presents evidence on the extent to which exchange rate movement pass through into import prices and on how exchange rate movements pass through into producer prices. This section examines the underlying mechanism, i.e. it investigates how

\footnotetext{
${ }^{10}$ Recent research by Nakamura and Steinson (2010) documents that pass through coefficients estimated using micro data may be biased since many price changes occur when firms discontinue old product lines and replace them with slightly modified ones. The producer price indices are somewhat less affected by this problem (although not altogether free of it), since the BLS takes into account quality and price changes when it observes that a product is discontinued and replaced by a slightly modified one.
} 
import prices changes that are themselves induced by exchange rate changes in turn affect producer prices. To the best of the author's knowledge, this study is the first to quantify this effect.

Tables 3 and 4, as well as Figure 5, examine the rate of how changes in import prices pass through into producer prices. Consider first Table 3. In Columns (1) and (2), the dependent variable is the monthly change in the producer price at the 5 digit NAICS level and the fixed effects panel estimations include a trend.

An important question one could ask is why not use the information of import prices instead of the exchange rate to estimate the rate at which import prices affect producer prices? Columns (1) and (2) serve to document the difference between these two approaches. In the OLS panel specification in Column (1), the only independent variable is the 1-month contemporaneous change in the sector's import price. The Two-Stage Least Square (2SLS) estimation presented in Column (2) instruments for this change in the import price with the 1-month change in the yuan exchange rate. Since the first stage is identical to the estimation of Column (1) in Table 1, it is omitted from Table 3. To test for weak identification, the bottom of Table 1 reports the p-value associated with Anderson's canonical correlation LR statistic and the Cragg-Donald F statistic. The 2SLS estimation reveals that the effect of import competition is larger than an OLS estimation would suggest: the coefficient is estimated at 0.91, more than three times the point estimate in Column (1). ${ }^{11}$

Columns (3) and (4) again compare the OLS to the 2SLS estimates, this time at the 3-months horizon. For this horizon, the 2SLS estimate and the OLS estimate differ less: while the OLS estimation predicts that a 1\% change in the average import price index is associated with a $0.512 \%$ change in the average producer price, the 2SLS estimation predicts that the same change is associated with $0.692 \%$ change in producer prices.

In order to gauge whether the results of Columns 1 to 4 are representative also for other horizons, Figure 5 presents the pass-through coefficient for the OLS and 2SLS specifications estimated at horizons up to 24 months. As in earlier graphs, also the upper and lower borders of the $95 \%$ confidence interval for each pass-through coefficient are reported. At most horizons (expect the 1-month and at horizons over 20 months), the coefficient is stable throughout time and estimated at roughly 0.7 for the 2SLS estimations in contrast to roughly 0.6 for the OLS Estimations

Since the analysis in Figure 5 suggests that the pass-through coefficient is comparable for different horizons between 3 and 20 months of length, I continue with some robustness analysis for the 3-months horizon in Table 3.

Columns (5) to (7) add the lagged 3 -months change in the import price (i.e. the change in the price from months -6 to -3$)$ to the estimation. This is done for the OLS specification in Column (5) and for the 2SLS specification in Column (6). Column (7) does not simply add the lagged 3-months change in the sector's import price to the specification, but rather instruments for it. In order to be able to instrument for two endogenous variables, also

\footnotetext{
${ }^{11}$ I have also analyzed whether the proposed two-stage estimation can pick up the indirect impact of import prices for ROW exchange rate changes, which is not the case. If one instruments for import prices with movements of the ROW exchange rate, the first-stage estimation is often weakly identified and the second-stage coefficients vary greatly with the chosen pass-through horizon, sometimes yielding negative rates.
} 
the lagged 3-months change of the yuan exchange rate is added as an instrument to the first-stage estimation.

The specifications of Columns (5) to (7) imply that also lagged changes in import prices have an effect on consumer prices. However, while the coefficient is estimated at around 0.1 when this variable is directly added to the specification, it is estimated at 0.37 when also this variable is instrumented for.

Columns (5) to (10) suggest that OLS estimations fail to pick up the correct timing of the pass through of import prices into producer prices. Consider, for example, the estimations including the 3-months change in the import price and the lagged 3-months change in Columns (5) and (7). The OLS estimation in Column (5) predicts that the timing is rather instantaneous with the coefficient of the contemporaneous import price change estimated at 0.5 and the one for the lagged change at 0.12 . The specification where both these lags are instrumented for, in contrast, estimates the contemporaneous import price change coefficient to be only 0.42 , while the coefficient for the lagged change is estimated at 0.37 .

To further investigate the extent to which lagged changes in import prices matter for current producer price dynamics, the next specification adds two more lags of the 3-months exchange rate change, i.e. the exchange rate changes 12-9 and 9-6 months ago. The OLS panel estimation is presented in Column (8), the basic 2SLS specification with only the 3-months exchange rate movement instrumented for in Column (9), and the full 2SLS specification with all four exchange rate movements instrumented for in Column (10). Again, all three specifications suggest that also lagged changes are of importance for current changes in producer prices, and again, this is more pronounced in the specification with also the lags instrumented for.

A word of caution is in order regarding the estimation in Column (10), which includes four endogenous variables and four instruments. Although the Anderson canonical correlation statistics suggests that the specification is well identified, the Cragg-Donald F statistic is estimated at only 2.34 (Stock and Yogo do not report critical values for more than 3 lags).

To make sure that the 2SLS estimations at longer horizons are well-identified, Table 4 again examines the timing dimension of pass through. In Columns (1) to (6), the dependent variable is the cumulated 3-months change of the US producer price at the 5-digit NAICS level.

In the OLS panel estimations in Column (1) and in the 2SLS estimation in Column (2), the independent variable includes the 3-months change in the corresponding import price at the 5-digit NAICS level. In addition, the estimation includes 3 auto regressive terms: the 3rd, 6th, and 9th lag of the 3-months change in the producer price. Again, the results indicate that the OLS estimation underestimates the impact of import prices on US producer prices. Both OLS and 2SLS estimations suggest that there is quite a pronounced autoregressive pattern of prices.

To further investigate the timing of the pass through of import into producer prices, I next add the 3-months lag of the import price change in Columns (3) and (4). This specification reveals that the overall 6 -months pass-through rate (sum of the coefficients 
for the 3-months change and the lagged 3-months change) is estimated at 0.93 in the 2SLS estimation, nearly twice the estimate (0.48) in the OLS estimations. Columns (5) and (6) add further autoregressive terms to this specification, confirming the previous finding that producer prices strongly mean-revert. The overall 6-months pass through rate (sum of the coefficients for the 3 -months change and the lagged 3 -months change) is estimated at 0.82 in the 2SLS estimation, which is substantially larger than the OLS estimate of 0.46 .

In order to be able to instrument for import prices at longer horizons, the next specifications include 6-months changes instead of 3-months changes, enabling me to study pass through up to a year while including (and instrumenting for) only two endogenous variables. In Columns (7) and (8), the dependent variable is the 6-months change in the producer price. The independent variables include lags of the producer price change up to the 24-months horizon and changes in import prices up to the 12-months horizon. For this specification, the overall 12-months pass-through rate is estimated comparable for the 2SLS and OLS estimations (sum of the coefficients for the 6-months change and the lagged 6 -months change equals 0.96 vs. 0.87 ). However, the difference in the timing of the impact in the two specifications is even more pronounced than in the other specifications: while the contemporaneous and the lagged coefficient are estimated at 0.51 and 0.27 respectively in the OLS estimation, the timing of pass through is roughly reversed in the 2SLS estimation. In the latter specification the contemporaneous and the lagged coefficient are estimated at 0.28 and 0.58 respectively.

Throughout Table 4, two main patterns stand out. First, OLS estimations understate the impact of import prices on producers prices by about a third. Second, OLS estimations also do not get the timing right: while the 2SLS estimations predict that it takes some time until import prices feed into producer prices, the OLS estimations predict that the impact is mostly instantaneous.

\section{Heterogeneous Pass Through Rates Across Sectors}

So far, the analysis unveils that changes in the yuan-dollar exchange rate and the associated import price movements have a large effect on US producer prices. Next, I want to dig somewhat deeper into the determinants of the rate of pass though into import and producer prices at the sectoral level.

In this section, I thus relate the pass-through rate to sector characteristics such as labor intensity, openness to trade, elasticity of demand, importance of traded intermediate goods in production, and openness to trade. Doing so helps to understand the microeconomics behind how exchange rates ultimately affect inflationary pressure, and moreover, these exercises are also helpful for refining the simulations of the inflationary effect of a potential appreciation of the yuan undertaken in Section 9 below.

A heterogeneous response of producer prices to exchange rate changes may derive from either a differing response of import prices to the exchange rate or from the differing response of producer prices to import prices. The analysis thus proceeds with two different sets of empirical test. In the first set of tests, reduced-form estimations that directly relate yuan changes to changes of producer prices are presented for various subsamples. In the 
second set of tests, the 2SLS estimation results for the various subsamples are presented.

Table 5 presents reduced-form estimations relating changes in the yuan/dollar exchange rate to changes in producer prices. Although this has the cost of losing some interpretability (owing to the lack of a first stage) it comes at the benefit of having a much larger sample, since producer prices are available for 320 sectors, while there are only 110 import prices.

The structure of Table 5 is the following. I present four different types of pass-through regressions in Panels A, B, C, and D. In Panels A and B, the dependent variable is the 3 -months change in the producer price. In Panel A, the only independent (in addition to fixed effects and a trend) variable is the contemporaneous 3-months exchange rate change. In Panel $\mathrm{B}$, a lag of the latter variable is added to the estimation. In Panels $\mathrm{C}$ and $\mathrm{D}$, the dependent variable is the 6 -months change in the producer price. In Panel $\mathrm{C}$, the only independent (in addition to fixed effects and a trend) variable is the contemporaneous 6 -months exchange rate change. In Panel $\mathrm{D}$, a lag of the latter variable is added to the estimation. For these four types of pass-through regression, the sample is next always split by a sector-specific characteristic.

It is important that these sector characteristics fulfill two requirements. First, each characteristic needs to be stable throughout time, so that the sample included in each of the columns of Table 5 is stable throughout time. This is important, since for example changes in labor intensity could be driven by exchange rate movements themselves so that not keeping the sample split stable would induce the sample composition to be correlated with the dependent variable.

Second, these characteristics should not be affected by demand conditions in China or the US during the period studied in this paper.

What is needed to split the sample is an external measure of an industry's intrinsic characteristics, i.e., a variable reflecting the fact that in some industries there are technological reasons to use more labor or more traded inputs than in other industries. I thus use only US industry information before December 2003 to construct these measures, implicitly assuming that if is true that in the United States in the years leading up to 2004, the production of one good requires relatively more inputs or labor than the production of another good, the same is true for Chinese imports at the current juncture.

In Columns (1) and (2), the sample is split by average labor intensity, which is taken from Auer and Fischer (2010) and defined as the ratio of expenditures on labor divided by expenditures on capital in the US. Auer and Fischer use information from the BLS' Annual Survey of Manufacturing to calculate the latter expenditures, and they also average the labor intensity throughout time so that the resulting variable does not vary within a NAICS 5 - or 6-digit sector.

$$
\text { Labor Intensity } \text { In }_{j}=\frac{\sum_{97-03} U S \text { Labor Expenditures }}{\sum_{97-03} U S \text { Capital Expenditures }}
$$

All four different estimations of Panels A to D reveal that the rate of pass-through into producer prices is much higher in sectors with relatively more capital expenditures as compared to labor expenditures. For example, while the 3-months rate of pass through (see Panel A) is 0.24 in the sample of labor intensive sectors, it is estimated at 0.77 in the 
rest of the sample. These economic magnitudes are roughly confirmed by the estimations including lags at the 6-months horizon. In addition, it seems that pass through is rather lagged in capital intensive sectors, while it happens rather contemporaneously in the rest of the sample.

In Columns (3) and (4), the sample is split by the elasticity of demand, taken from Broda and Weinstein (2006). As is to be expected, the pricing response is larger in sectors with elastic demand. Panels B and D do not unveil differences in the time profile at which exchange rate changes pass through into prices.

In Columns (5) and (6), the sample is split by input intensity, defined following Schott (2004). Trade flows at the 10-digit Harmonized System (HS) that contain the words "Input", "Part", "Intermediates" and variants thereof in the good description are classified to contain intermediate goods. The resulting dummy is then aggregated to the 6-digit NAICS level taking into account the weight of each 10-digit HS goods in the respective 6 -digit NAICS sector. The resulting variable thus measures the (volume-weighted) fraction of 10-digit HS goods within a 6-digit NAICS sector that includes intermediate goods (and can take any value between 0 and 1 ).

The estimation in Column (5) includes sectors that do not contain any intermediate goods (i.e. it includes only final consumption goods) and the estimation in Column (6) includes only sectors with at least some intermediate goods. The rate of pass through is much higher in the sample of Column (5) containing only final goods. Moreover, Panels B and $\mathrm{D}$ reveal that pass through is also more contemporaneous in sectors with final goods.

Sectors also differ substantially along many technological characteristics that determine whether the sector is more or less open to trade in equilibrium, which in turn might affect the equilibrium pass-through rate. In order to summarize all these characteristics, I next build a measure of trade openness to the rest of the world, defined by how much of the non-Chinese consumption in a sector (total US consumption minus US imports from China) originates from the rest of the world (total imports minus imports from China). The sample in Columns (7) and (8) is thus split by:

$$
R O W \text { Import Penentration }_{j}=\frac{\sum_{97-03} \text { Imports World }_{j}-\text { Imports China }_{j}}{\sum_{97-03} \text { US Consumption }_{j}-\text { Imports China }_{j}}
$$

Columns (7) and (8) document that in sectors more open to the ROW, pass through into producer prices is somewhat higher than in other sectors. There is no dramatic difference in the timing of pass through between open and less open sectors.

Overall, Table 5 presents evidence that rate of pass through differs starkly between sectors with different characteristics. In order to get an understanding of why this is the case, Table 6 presents the same sample splits as does Table 5, but this time for the 2SLS estimations where import price changes are instrumented for with exchange rate movements. In Panel B, also the second-stage is estimated for each sample split separately.

The exercise of Table 6 can show if the reduced from differences in pass-through rates found in Table 5 stem from either a difference in how exchange rates affect import prices, or from how import prices affect producer prices.

The structure of Table 6 is the following. The bottom Panel A presents the first-stage relation between exchange rate movements and import prices. The middle Panel B presents 
the second-stage estimation relating instrumented import prices to producer prices. Last (presented mostly for the sake of completeness), the top panel C presents the OLS relation between import prices and producer prices. As in the preceding Table, the sample is split by labor intensity (Columns (1) and (2)), demand elasticity ((3) and (4)), intermediate good intensity ((5) and (6)), and trade openness to the rest of the world ((8) and (9)).

The main takeaway from Table 6 is that while there is rather little heterogeneity in how import prices affect producers prices, there is substantial heterogeneity in how exchange rate movements pass through into import prices. Consider first the second-stage estimation in Panel B. The rate of how import prices pass through into import prices is economically very comparable for the case of labor intensity and demand elasticity. ${ }^{12}$ There is some heterogeneity in the rate at which import prices pass through into producers prices when splitting up the sample by openness to the rest of the world.

However, for all the four characteristics along which the sample is split up, there is a large degree of heterogeneity in the first-stage coefficients. For example, a 10\% appreciation of the yuan is associated with a $9.678 \%$ import price increase in those sectors that contain no intermediate goods (see Column (5)), but only a $3.557 \%$ increase in sectors that do contain intermediate goods (see Column (6)), i.e. the pass-through rate into import prices is a factor three smaller. In contrast, the differences in the pass-through rate of import into producer prices (0.7551 in (5) compared to 0.5952 in (6)) are much smaller.

\section{The Heterogeneity of Pass Through and Identifica- tion}

The previous analysis finds that there is an economically quite significant difference in the extent to which import prices are affected by exchange rates, whereas the rate at which import prices pass into producer prices is rather homogenous across the sectors. This section utilizes this pattern in the data to examine the exogeneity of the yuan appreciation more closely.

The fact that the response of import prices to the exchange rate is heterogeneous across sectors makes it possible to further test the 2SLS specifications. The latter are implicitly assuming that changes in the yuan exchange rate affect producer prices exclusively via their impact on import prices. To test this assumption, this section adds interactions of the exchange rate with a sector characteristics to the estimation as additional instruments.

Why is adding interaction instruments a meaningful exercise? To fix ideas, index sectors by $j$ and denote changes in a sector's import and producer price by $\Delta I P_{U S, j}$ and $\Delta P P_{U S, j}$ respectively and a change in the exchange rate by $\Delta e_{U S}$. The determinants of prices are

$$
\begin{aligned}
\Delta P P_{U S, j} & =\alpha_{P P}+\beta \Delta I P_{U S, j}+\epsilon_{P P, t}+\epsilon_{P P, j, t} \\
\Delta I P_{U S, j} & =\alpha_{P I}+\gamma_{j} \Delta e_{U S}+\epsilon_{P I, t}+\epsilon_{P I, j, t}
\end{aligned}
$$

\footnotetext{
${ }^{12}$ This claim is confirmed in a statistical sense by estimations that add the interaction between a sector characteristic and the exchange rate change: the interactions are not significant.
} 
For expositional clarity, (2) and (1) include both the aggregate shocks $\epsilon_{P P, t}$ and $\epsilon_{P I, t}$ and the sector-specific shocks $\epsilon_{P P, j, t}$ and $\epsilon_{P I, j, t}$ that are by definition of mean 0 . The coefficient measuring the impact of the exchange rate on import prices is sector-specific $\left(\gamma_{j}\right)$. If $\gamma_{j}=\gamma$, one can only examine the system formed by (2) and (1) if it is true that the exchange rate change is uncorrelated to the average shock of producer prices $\left(\Delta e_{U S} \perp \epsilon_{P P, t}\right)$, which seems reasonable since the yuan exchange rate is a managed currency.

However, if $\gamma_{j}$ is sector-specific, one can even test whether $\Delta e_{U S} \perp \epsilon_{P P, t}$ holds true in the data. To see this, consider two sectors $j \neq k$ and look at the difference in import and producer price changes.

$$
\begin{aligned}
\Delta P P_{U S, j}-\Delta P P_{U S, j} & =\beta\left(\Delta I P_{U S, j}-\Delta I P_{U S, k}\right)+\left(\epsilon_{P P, j, t}-\epsilon_{P P, k, t}\right) \\
\Delta I P_{U S, j}-\Delta I P_{U S, k} & =\left(\gamma_{j}-\gamma_{k}\right) \Delta e_{U S, j}+\left(\epsilon_{P I, j, t}-\epsilon_{P I, k, t}\right)
\end{aligned}
$$

Given that differences in how import prices are affected by the exchange rate identifies differences in import prices, the 2SLS estimation can also be identified if $\Delta e_{U S} \perp \epsilon_{P P, t}$ is violated.

Table 7 presents estimations that use one of the interactions of the four sector characteristics and the exchange rates as instruments. One instrument (the exchange rate) satisfies the exclusion restriction only if $\Delta e_{U S} \perp \epsilon_{P P, t}$ holds, while the other instrument (the interaction) satisfies the exclusion restriction also if the latter is not the case. Therefore, an overidentification test implicitly tests whether $\Delta e_{U S} \perp \epsilon_{P P, t}$ holds true in the data. In Table 7, each sector characteristic (labor intensity in, demand elasticity, input intensity, and ROW trade openness) is standardized so that the main coefficient for exchange rate changes is unaffected by the addition of the interaction term.

The structure of Table 7 is the following. Panel A presents the first-stage estimation relating the exchange rate and its interaction to changes in import prices. The estimations presented in Columns (1), (3), (5), and (7) of Panel A include the change in the yuan rate and the interaction of this change with a sector characteristic as instruments. The specifications in Columns (2), (4), (6), and (8) of Panel A include time dummies so that the change of the exchange rate - an aggregate variable - drops out of the estimation. Panel B presents the second-stage estimation results relating the instrumented change in import prices to the change in the producer price.

The specification of Column (1) instruments for the change in the import price with the exchange rate change and with the interaction of exchange rate change and labor intensity (since all estimations include fixed effects, the labor intensity itself is not included). Since there are two instruments and only one endogenous variable, one can test the overidentified system for the mutual consistency of the two instruments. The bottom of Panel A reports the p-value associated with the Hansen J-statistic. In Column (1), the latter p-value is 0.46, i.e. there is absolutely no evidence that the two instruments are mutually inconsistent. The latter is also confirmed by the fact that the second-stage coefficients are not affected by the addition of the second instrument: with both instruments included, the rate at which import prices pass through into producer prices is 0.7098 (See Panel B, Column (1), Table 7 ), very similar to rate found when instrumenting with the exchange rate only (coefficient of 0.691, see Column (4) of Table 3). 
There is a second advantage of adding the interaction as an additional instrument. While the exchange rate varies only over time, the interaction of sector characteristics and exchange rate changes varies both by sector and time, thus allowing to filter out all aggregate month-to-month variation while still identifying the effect of import prices on producer prices. Column (2) adds time dummies to the specification of Column (1). Since the yuan exchange rate change is an aggregate variable, this variable is dropped from the estimation.

The estimation of Column (2) documents that also when filtering out all aggregate month-to-month variation (filtered out by the addition of time dummies) and all sector averages (filtered out by the fixed effects), there is a strong relation between import price changes and the interaction of exchange rate changes and labor intensity. Also the secondstage coefficient for the effect of import prices on producer prices remains highly significant and is comparable in magnitude to the previous findings (0.756, see Panel B of Column $(2))$.

The rest of Table 7 repeats the exercises of Columns (1) and (2) for interactions of the exchange rate with different sector characteristics. In Columns (3) and (4), the exchange rate interacted with the elasticity of demand is added to the specification. The second-stage coefficient and the overidentification test in Column (3) suggest that also this interaction instrument confirms the findings of the analysis when using only the exchange rate as an instrument. However, the estimation in Column (4) reveals a simpler truth: the interaction of demand elasticity and exchange rate changes is simply not a powerful instrument once all the aggregate variation is eliminated from the data by including time dummies. In this specification, the p-value associated with the Anderson Canonical correlation statistic is equal to 0.09 , i.e. this identification is weakly identified.

Columns (5) and (6) instead add the interaction of the exchange rate with the sector's input intensity, again finding results that are nearly identical to when only the yuan exchange rate is included as instrument. The same is true when the interaction of the sector's openness to the rest of the world with the exchange rate change is added to the estimation in Columns (7) and (8).

Overall, Table 7 reveals that instrumenting with the interactions of sector characteristics and exchange rate changes confirms the findings of the previous analysis using only the yuan/dollar exchange rate as an instrument. Columns (1) and (2) of Table 8 show that this is also the case when adding all four interactions as instruments at the same time. Column (1) thus includes five instruments (the exchange rate and four interactions), while Column (2) includes time dummies and four instruments. Correspondingly, while the overidentification test of Column (1) tests whether the five instruments are internally consistent, the one presented in Column (2) only tests whether the four interactions yield mutually consistent estimates for the second-stage coefficient of import prices on producer prices. Both tests cannot be rejected at the $10 \%$ significance level.

Columns (3) and (4) of Table 8 repeat the specification with all four interactions added as instrument, but do this at the 6-months horizon rather than the 3-months horizon. Again, the overidentification tests do not rejected the hypothesis that the instruments are mutually consistent, and eliminating the exchange rate by adding time dummies in Column 
(4) does not considerably influence the second-stage point estimate. Columns (5) and (6), in turn, find the same patters at the 1-month horizon. Last, Columns (7) and (8) again estimate pass through into producer prices at the 3 -months horizon, but add autoregressive terms to the specification, a refinement which matters, but again does yields the result that these five instruments are mutually consistent.

The analysis of this section, presented in Tables 7 and 8, has further tested the assumption that the yuan exchange rate changes can be used as an instrument for import prices. The key insight was taken from Section 6 above that there is heterogeneity in the degree to which exchange rates pass through into prices. In this section, this heterogeneity was utilized to further test the exogeneity of the yuan appreciation to US demand conditions. ${ }^{13}$

\section{The Response of Import Volume to Yuan Changes}

The above analysis concentrates on the price response to exchange rate movements. I next briefly investigate the response of import volume. Of course, given the prominence the "global imbalances" topic has received in the press such an exercise has been attempted in numerous studies before (see the various studies undertaken and summarized in Claessens et al. (2010)). However, the dataset in this study contains only sectors for which information on prices is available, thus making it worthwhile to evaluate whether the quantity response in this sample is comparable to the findings of the existing literature.

Figure 6 presents the cumulative response of the volume of imports from China (changes of the natural logarithm of dollar import volume) at various horizons. The coefficients displayed in this figure are computed in the following way. For each N-months Horizon, Figure 6 presents the change of "Cumulative Change of $\$$ Import Volume over last N Months" as dependent variable on "Cumulative Exchange Rate Change over last N Months" as independent variable, where $\mathrm{N}$ can take values from 1 to 36 . Also the associated $95 \%$ CI for each horizon is displayed.

There is no response of import volume up to horizons of 16 months. Thereafter, the response is increasingly negative and the elasticity gradually increases in magnitude to around -5 after two and a half years. Thereafter, it roughly stays constant at this level.

\section{Appreciation Scenarios}

I next use the findings of the above analysis to estimate the inflationary impulse of a yuan appreciation on the US general producer price inflation rate. For these predictions, I combine the previous findings and account for the fact that pass through is heterogeneous along

\footnotetext{
${ }^{13}$ The findings of this section raise the question of why not to instrument for pass through of the ROW exchange rates with the interaction of the ROW exchange rate changes and sector characteristics. Although such estimations are consistent with the findings presented here, the results using the ROW exchange rate are often not significant, resulting in weak identification problems. Therefore no estimation using the ROW exchange rate is presented in either Table 7 or 8 .
} 
the dimension of input and labor intensity and along the dimension of demand elasticity. ${ }^{14}$ The simulations account for the fact that exchange rate changes might affect producer prices only with a lag and also, that producer prices themselves have an autocorrelation structure. Last, each sectoral pass-through rate is multiplied by its weight in the official US PPI. Since the total weight of the sectors included in this study is less than $30 \%$ of the PPI, the magnitude of the overall effects as a percentage of the PPI is about a third than what the coefficients in the analysis above suggest.

A brief discussion of the external validity of the coefficients that are derived from the 2005-2008 experience to a potential appreciation at the current juncture is in order. What is crucial for these coefficients to be externally valid today is whether the current situation is comparable to 2005-2008 in the following sense: during that period of time, Chinese policy makers revalued their currency due to political pressure from the US and they did it by attaching a substantial weight on the euro and on other currencies when setting their exchange rate. As the euro rose against the dollar, also the yuan appreciated against the US dollar.

Also today, the dollar has substantially depreciated against the euro compared to 2008 and there is ample political pressure demanding that China revalue its currency. Therefore, both the macroeconomic and the political circumstances during 2005-2008 are comparable to the current backdrop. Consequently, the point estimates derived from the 2005-2008 appreciation contain valid information that can be used to establish the effects of an appreciation at the current juncture.

Figure 7 presents the size of the total relative shock in terms of the US PPI inflation rate, i.e. it answers to the following counterfactual. Assume that the yuan appreciates, that the prices of traded goods respond as described in the above analysis and also that this relative price shocks

inflationary impulse of two different yuan-revaluation scenarios. For each scenario, Figure 7 displays the impulse on the annual inflation rate, i.e. the predicted year-overyear inflation rate with the appreciation minus the predicted year-over-year inflation rate without the appreciation. The red solid line corresponds to a scenario where the yuan appreciates for 10 months at a rate of $2.5 \%$ per month. The total predicted impact on the US PPI peaks at well over 5 percentage point around the end of the 10 months appreciation window. For the second scenario where the yuan appreciates at $1 \%$ per month for 25 months, the total impact on the PPI does not exceed positive 2 percentage points, but it is also quite more long-lived: the total shock on the US producer price index exceeds 1 percentage point for a period of nearly two years.

Figure 7 documents that a yuan revaluation would result in a sizeable relative price shock. On theoretical grounds, however, it is not clear that relative price shocks affect equilibrium inflation, because price decreases by firms experiencing substantial import competition could be offset by price hikes in other parts of the economy. Ball and Mankiw (1995) note in this context that one needs to evaluate the distribution of price shocks. Ball and

\footnotetext{
${ }^{14} \mathrm{I}$ do not account for the fact that pass through rates differ along the dimension of trade openness to the rest of the world since one could be worried that this measure reflects an equilibrium outcome of the current macroeconomic situation rather than a technological characteristic.
} 
Mankiw argue that in the presence of menu costs, firms adjust their prices to large external shocks but not to small shocks. Therefore, large shocks have disproportionate effects on the price level and aggregate inflation depends on the distribution of relative-price changes: inflation rises when the distribution is skewed to the right and falls when the distribution is skewed to the left.

Figure 8 examines the sectoral distribution of price shocks that result from the yuan appreciation. It reports two univariate kernel density estimates for the $25 \%$ appreciation of the yuan spread over either 10 months (red solid line) or 25 months (orange dashed line). The size of the monthly price shock in each sector is measured as a percentage and is displayed on the horizontal axis, while the density (in sector-months observations) is displayed on the vertical axis. Figure 8 covers the 30 months after the appreciation.

Figure 8 reveals that a rapid appreciation (2.5\% per month) would lead to a strongly right -skewed distribution of relative price shocks. Thus, considerations like those of Ball and Mankiw (1995) imply that at this pace a yuan-revaluation is likely to also affect U.S. aggregate PPI inflation.

Interestingly, the effect on the distribution of relative price shocks is much more contained when the yuan raises at $1 \%$ per month. The reason for this is that the mean-reverting pattern of sectoral prices starts to be relevant around 9 months after the appreciation (and more thereafter). Since the sectors that are the most affected by the appreciation are also the ones where the mean-reversion has the most effect, the slower rate of appreciation leads to less extreme sectoral price shocks.

\section{Conclusion}

The course of US inflation over the next years may be closely intertwined with the resolution of global imbalances. The rise of cheap imports from China was a major contributing fact to the low inflation environment during the last decade. For the US, Auer and Fischer (2010) show that the rise of import competition from low wage countries has decreased US inflationary pressure by around half a percentage point during the last decade, and they also show that most of this was due to the rise of China. If an appreciation of the yuan is aimed at restoring a balanced US-Chinese current account and is successful in doing so, it seems straightforward that also the disinflationary effect will be reversed.

The analysis of this paper quantifies the relative price shock resulting from a yuan revaluation using a new estimation technique that investigates first the response of import prices on the yuan/dollar exchange rate, and then in a second step the consequent response of US producer prices.

The analysis finds much bigger effects that is commonly assumed. For example, in a sample of 110 manufacturing sectors, the rate of pass through into import prices is estimated at around 0.8 and into US producer prices it is estimated at around 0.5. Taking into account that the rate of pass through is heterogeneous across sectors, that the timing of pass through into producer prices matters, and that producer prices also have an autocorrelation structure, simulations reveal that a substantial revaluation of the yuan also would imply a substantial upward impulse on the prices of traded goods in the US. US policymakers need 
to take into account these considerations when deciding on their course of action regarding the trade policy versus China.

\section{References}

[1] Atkeson, Andrew and Ariel Burstein, "Pricing to Market, Trade Costs, and International Relative Prices,", American Economic Review, December 2008.

[2] Auer, Raphael A. and Thomas Chaney. (2007). "How do the Prices of Different Goods Respond to Exchange Rate Shocks? A Model of Quality Pricing-to-Market." Mimeo, University of Chicago.

[3] __ (2009). "Exchange Rate Pass-Through in a Competitive Model of Pricing-toMarket." Journal of Money, Credit and Banking, 41 (s1): 151-175.

[4] Auer, R. A. and A. M. Fischer, 2010. The effect of low wage import competition on U.S. inflationary pressure, Journal of Monetary Economics 57(4), 491-503.

[5] Auer, R. A., K. Degen and A. M. Fischer, 2010. "Globalization and Inflation in Europe" Mimeo Swiss National Bank

[6] Bacchetta, Philippe and Eric van Wincoop, 2003. "Why Do Consumer Prices React Less Than Import Prices to Exchange Rates?," Journal of the European Economic Association, MIT Press, vol. 1(2-3), pages 662-670, 04/05.

[7] Bailliu, Jeannine, and Eiji FujII, "Exchange Rate Pass Through and the Inflation Environment in Industrialized Countries: An Empirical Investigation," Bank of Canada working paper 2004-21 (2004).

[8] Ball, L. and N.G. Mankiw, (1995 ). "Relative-price changes as aggregate supply shocks", Quarterly Journal of Economics 110 (1) (1995), pp. 163-193.

[9] Baum, C. F., Caglayan, M. and Barkloulas, J. T. (2001), "Exchange Rate Uncertainty and Firm Profitability", Journal of Macroeconomics, 23, 565-576.

[10] Bernard, A. B., J. B. Jensen, and P. K. Schott, 2006 . Survival of the best fit: exposure to low-wage countries and the (uneven) growth of U.S. manufacturing plants. Journal of International Economics 68(1), 219-237.

[11] Bosworth, B (2004). Valuing the renminbi. Paper presented at the Tokyo Club Research Meeting, 9-10 February.

[12] Broda, Christian, and David Weinstein. (2006). "Globalization and the Gains from Variety." The Quarterly Journal of Economics, 121 (2): 541-585. 
[13] Bugamelli, M., S. Fabiani, and E. Sette, 2010. The pro-competitive effect of imports from China: an analysis of firm level price data, Temi di discussione 737, Bank of Italy.

[14] Bureau of Labor Statistics (2010)., BLS Handbook of Methods, Chapter 14 Producer Prices, Background (accessed online $201011 \quad 10$ at: http://www.bls.gov/opub/hom/homch14_a.htm).

[15] Burstein, A. and N. Jaimovich (2009), "Understanding Movements in Aggregate and Product-Level Real Exchange Rates," mimeo UCLA.

[16] Burstein, Ariel, Joao Neves, and Sergio Rebelo, "Distribution Costs and Real Exchange Rate Dynamics during Exchange Rate Based Stabilizations," Journal of Monetary Economics 50:6 (September 2003), 1189-1214.

[17] Burstein, Ariel, Martin Eichenbaum, and Sergio Rebelo, (2005) "Large Devaluations and the Real Exchange Rate," Journal of Political Economy, August 2005.

[18] __ "Modeling Exchange Rate Passthrough After Large Devaluations,", Journal of Monetary Economics, March 2007.

[19] Campa, José Manuel and Linda S. Goldberg (2005). "Exchange Rate Pass Through into Import Prices," Review of Economics and Statistics, 87:4 (2005), 679-690.

[20] Cheung, Y, M Chinn, and E Fujii (2010), "China's Current Account and Exchange Rate", in R Feenstra and S-J Wei (eds.), China's Growing Role in World Trade, University of Chicago Press.

[21] Claessens, Stijn, Simon Evenett and Bernard Hoekman (eds.) (2010)). Rebalancing the Global Economy: A Primer for Policymaking Published 23 June 2010 BY VoxEU.ORG

[22] Cline, William R (2010). "Renminbi Undervaluation, China's Surplus, and the US Trade Deficit", Peterson Institute for International Economics Policy Brief 10-20.

[23] Corsetti, Giancarlo and Luca Dedola, "Macroeconomics of International Price Discrimination," Journal of International Economics 67 (2005), 129-156.

[24] Corsetti, Giancarlo, Luca Dedola, and Sylvain Leduc, "Pass Through and Exchange Rate Fluctuations," manuscript, Board of Governeours of the Federal Reserve, (2004).

[25] Corsetti, Giancarlo, Pesenti Paolo, Nouriel Roubini and Credic Tille (2000). "Competitive devaluations: toward a welfare-based approach," Journal of International Economics, Elsevier, vol. 51(1), pages 217-241, June 
[26] Devereux, Michael B. and Charles Engel, "Exchange Rate Pass-Through, Exchange Rate Volatility, and Exchange Rate Disconnect," Journal of Monetary Economics 49 (2002), 913-940.

[27] Dornbusch, Rudiger (1987). "Exchange Rates and Prices," The American Economic Review, Vol. 77, No. 1., pp. 93-106. March 1987.

[28] M. Dotsey and R.G. King 2005, Implications of state-dependent pricing for dynamic macroeconomic models, Journal of Monetary Economics 52 (2005), pp. 213-242.

[29] Frankel, Jeffrey (2009), "New Estimation of China's Exchange Rate Regime", Pacific Economic Review ,14(3):346-360, August.

[30] _-_ (2010), "The renminbi since 2005." Colunmn, VoxEU.org, Published on 16 April 2010

[31] Frankel, J. A., D. C. Parsley, and S.-J. Wei (2005): "Slow Passthrough Around the World: A New Import for Developing Countries?," NBER Working Paper 11199.

[32] Frankel, Jeffrey and Shang-Jin.Wei (2007), "Assessing China's Exchange Rate Regime", Economic Policy, 51:575-614.

[33] __ (2008), "Estimation of De Facto Exchange Rate Regimes: Synthesis of the Techniques for Inferring Flexibility and Basket Weights", IMF Staff Papers 55:384-416.

[34] Froot, Ken A., and Paul D. Klemperer, "Exchange Rate Pass-Through When Market Share Matters," American Economic Review 79 (1989), 637-654.

[35] Gagnon, Joseph, and Jane Ihrig, "Monetary Policy and Exchange Rate PassThrough," Board of Governors of the Federal Reserve System, International Finance discussion papers no. 704 (July 2001).

[36] Geithner, Thimothy E. (2009), Remarks made at the Public Confirmation hearing by the US Senate Finance Committee on January 21st, 2009.

[37] Giovannini, A. (1988): "Exchange Rates and Traded Goods Prices," Journal of International Economics, (24), 45-68.

[38] Goldberg, Linda S. and José Manuel Campa (2010). "The Sensitivity of the CPI to Exchange Rates: Distribution Margins, Imported Inputs, and Trade Exposure" Review of Economics and Statistics, May 2010, Vol. 92, No. 2: 392-407.

[39] Goldberg, Linda S. and Tille, Cédric, 2008. "Vehicle currency use in international trade," Journal of International Economics, Elsevier, vol. 76(2), pages 177-192, December

[40] Goldberg, P. K., and M. Knetter (1997): Goods Prices and Exchange Rates: What Have We Learned?," Journal of Economic Literature, 35(3), $1243\{1272$. 
[41] Goldberg, Pinelopi K. and Frank Verboven (2005). "Market Integration and Convergence to the Law of One Price: Evidence from the European Car Market," Journal of International Economics, pp. 49-73, January 2005

[42] Goldberg, Pinelopi K. and Frank Verboven (2001). "The Evolution of Price Dispersion in European Car Markets", Review of Economic Studies, Oct. 2001, pp. 811-48.

[43] Gopinath, Gita and Oleg Itskhoki (2010a). "In Search of Real Rigidities" . NBER Macroeconomics Annual, 2010, Volume 25.

[44] __(2010b). "Frequency of Price Adjustment and Pass-through". Quarterly Journal of Economics, May 2010, Volume 125(2).

[45] Gopinath, Gita Oleg Itsknoni, and Roberto Rigobon (2010b) "Currency Choice and Exchange Rate Pass-through" American Economic Review, March 2010, Volume $100(1)$.

[46] Gopinath, Gita and Roberto Rigobon (2008). "Sticky Borders", Quarterly Journal of Economics, May 2008, Volume 123(2).

[47] Guerrieri, Luca, Gust, Christopher, and David Lopez-Salido (2010) "International Competition and Inflation: A New Keynesian Perspecitve" , American Economic Journal: Macroeconomics, vol. 2 (October 2010), pp. 247-280

[48] Gust, Christopher, Sylvain Leduc and Vigfusson "Trade Integration, Competition, and the Decline in Exchange-Rate Pass-Through", Journal of Monetary Economics 57, April 2010, 309-324.

[49] Hellerstein, Rebecca, 2008. "Who bears the cost of a change in the exchange rate? Pass-through accounting for the case of beer," Journal of International Economics, Elsevier, vol. 76(1), pages 14-32, September.

[50] Imbs, Jeans, Haroon Mumtaz, Morten Ravn and Hélène Rey. "PPP Strikes Back: Aggregation and the Real Exchange Rate", Quarterly Journal of Economics, February 2005.

[51] International Monetary Fund, (2007), World Economic Outlook Spillovers and Cycles in the Global Economy (Washington, DC: IMF, 2007).

[52] International Monetary Fund (2008), World Economic Outlook, 2008. How has globalization affected inflation?, Chapter 3, 97-134.

[53] Knetter, Michael (1989). "Price Discrimination by U.S. and German Exporters," Amer. Econ. Rev.,Mar. 1989, 79(1), pp. 198-210.

[54] __ (1993)."International Comparisons of Price-to-Market Behavior," Amer. Econ. Rev., June 1993, 83(3), pp. 473-86. 
[55] Melitz, Marc J., and Gianmarco Ottaviano. (2008). "Market Size, Trade, and Productivity." Review of Economic Studies, 75 (1): 295-316.

[56] Nakamura, Emi and Jón Steinsson (2010) "Lost in Transit: Product Replacement Bias and Pricing to Market" Mimeo, Columbia University.

[57] Nakamura, Emi and Dawit Zerom (2010) "Accounting for Incomplete PassThrough" Review of Economic Studies, 77(3), 1192-1230, July 2010.

[58] Ottaviano, G. I. P., Tabuchi, T. and Thisse, J.-F. (2002), "Agglomeration and Trade Revisited", International Economic Review, 43, 409-436.

[59] Overholt, William. "Exposing the Myths," South China Morning Post, November $17,2003$.

[60] Rogoff, Kenneth, "Impact of Globalization on Monetary Policy," in Federal Reserve Bank of Kansas City, The New Economic Geography: Effects and Policy Implications (2007).

[61] Rynn, Jonathan M. "Why Manufacturing and the infrastructure are central to the economy: A global vision of peace, prosperity, democracy, and ecological sustainability" posted on www.economicreconstruction.com on 11/1/2005.

[62] Sснотт, Peter K. (2004). "Across-product versus within-product specialization in international trade." The Quarterly Journal of Economics, 119 (2): 647-678.

[63] Taylor, J. B. (2000), "Low Inflation, Pass-Through and the Pricing Power of Firms", European Economic Review, 44, 1389 - 1408.

[64] Verboven, Frank (1996). "International Price Discrimination in the European Car Market," Rand J. Econ., Summer 1996, 27(7), pp. 240-68.

[65] YANG, Jiawen (1997). "Exchange Rate Pass-Through in U.S. Manufacturing Industries," The Review of Economics and Statistics, Vol. 79, No. 1. pp. 95-104., February 1997. 


\begin{tabular}{|c|c|c|c|c|c|c|c|c|}
\hline & (1) & (2) & (3) & (4) & (5) & $(6)$ & (7) & (8) \\
\hline & Yuan, 1 Month & Yuan, 3 Months & Yuan, 1 Year & adding AR Terms & Others, 1 Month & Others, 3 Months & Others, 1 Year & adding AR Terms \\
\hline & Horizon & Horizon & Horizon & (1 Year) & Horizon & Horizon & Horizon & (1 Year) \\
\hline & \multicolumn{8}{|c|}{ Dependent Variable is the 1 Month Change in the US Import PPI at the Naics 5 Digit Level } \\
\hline & \multicolumn{8}{|c|}{ Independet Variables: Changes in Exchange Rate Against USD (positive change means Dollar Depreciates) } \\
\hline & \multicolumn{4}{|c|}{ (1)-(4): Changes in In(USD per Yuan) } & \multicolumn{4}{|c|}{ (5)-(8): Ch. In Trade Weighted Exch. Rate (Excl. Yuan) } \\
\hline \multirow[t]{2}{*}{1 Month Change } & 0.4622 & 0.2873 & 0.178 & 0.3122 & 0.0565 & 0.0071 & 0.0087 & -0.0127 \\
\hline & {$[0.0651]^{* *}$} & {$[0.0892]^{* *}$} & {$[0.0898]^{*}$} & {$[0.0751]^{* *}$} & {$[0.0173]^{* *}$} & [0.0189] & [0.0209] & [0.0181] \\
\hline \multirow[t]{2}{*}{ Lag 1 of 1-Month Change } & & 0.5326 & 0.507 & 0.448 & & 0.0802 & 0.086 & 0.0634 \\
\hline & & {$[0.0819]^{* *}$} & {$[0.0892]^{* *}$} & {$[0.0759]^{* *}$} & & {$[0.0207]^{* *}$} & {$[0.0207]^{* *}$} & {$[0.0182]^{* *}$} \\
\hline \multirow[t]{2}{*}{ Lag 2 of 1-Month Change } & & -0.1911 & -0.0534 & -0.1608 & & 0.1558 & 0.1632 & 0.1569 \\
\hline & & {$[0.0882]^{*}$} & [0.0969] & {$[0.0820]^{*}$} & & {$[0.0188]^{* *}$} & {$[0.0212]^{* *}$} & {$[0.0190]^{* *}$} \\
\hline \multirow[t]{2}{*}{ Lag 3 of Cum. 3-Months Change } & & & 0.045 & -0.0303 & & & 0.0549 & 0.0116 \\
\hline & & & {$[0.0411]$} & {$[0.0398]$} & & & {$[0.0090]^{* *}$} & [0.0079] \\
\hline \multirow[t]{2}{*}{ Lag 6 of Cum. 3-Months Change } & & & -0.1891 & -0.0676 & & & 0.0082 & 0.0017 \\
\hline & & & {$[0.0341]^{* *}$} & {$[0.0378]$} & & & {$[0.0098]$} & {$[0.0085]$} \\
\hline \multirow[t]{2}{*}{ Lag 9 of Cum. 3-Months Change } & & & -0.1174 & -0.0456 & & & 0.053 & 0.053 \\
\hline & & & {$[0.0299]^{* *}$} & {$[0.0319]$} & & & {$[0.0109]^{* *}$} & {$[0.0106]^{* *}$} \\
\hline \multicolumn{9}{|c|}{ Autorregressive Terms: Lagged Changes in the US Import PPI at the Naics 5 Digit Level } \\
\hline \multirow[t]{2}{*}{ Lag 1 of 1-Month Change } & & & & 0.2242 & & & & 0.2231 \\
\hline & & & & {$[0.0170]^{* *}$} & & & & {$[0.0168]^{* *}$} \\
\hline \multirow[t]{2}{*}{ Lag 2 of 1-Month Change } & & & & 0.0548 & & & & 0.0665 \\
\hline & & & & {$[0.0172]^{* *}$} & & & & {$[0.0171]^{* *}$} \\
\hline \multirow[t]{2}{*}{ Lag 3 of Cum. 3-Months Change } & & & & 0.0236 & & & & 0.018 \\
\hline & & & & {$[0.0084]^{* *}$} & & & & {$[0.0084]^{*}$} \\
\hline \multirow[t]{2}{*}{ Lag 6 of Cum. 3-Months Change } & & & & -0.079 & & & & -0.0722 \\
\hline & & & & {$[0.0080]^{* *}$} & & & & {$[0.0082]^{* *}$} \\
\hline \multirow[t]{2}{*}{ Lag 9 of Cum. 3-Months Change } & & & & 0.0037 & & & & 0.0045 \\
\hline & & & & {$[0.0086]$} & & & & {$[0.0084]$} \\
\hline Fixed Effects by Sector & $\mathrm{y}$ & y & $\mathrm{y}$ & $\mathrm{y}$ & y & y & $\mathrm{y}$ & $\mathrm{y}$ \\
\hline Trend & $\mathrm{y}$ & $\mathrm{y}$ & $\mathrm{y}$ & $\mathrm{y}$ & $\mathrm{y}$ & y & $\mathrm{y}$ & $\mathrm{y}$ \\
\hline Observations & 4844 & 4840 & 4837 & 3627 & 4844 & 4840 & 4837 & 3627 \\
\hline Number of Groups & 110 & 110 & 110 & 110 & 110 & 110 & 110 & 110 \\
\hline R-squared & 0.01 & 0.02 & 0.04 & 0.16 & 0.01 & 0.03 & 0.05 & 0.17 \\
\hline \multicolumn{5}{|c|}{ Standard errors in brackets; ${ }^{*}$ significant at $5 \% ;{ }^{* *}$ significant at $1 \%$} & & & & \\
\hline
\end{tabular}


Table 2 - Pass Through Rate Es timated Separately Within Each 3 Digit NAICS Indus try (Cum 3-months PT Rate)

\begin{tabular}{|c|c|c|c|}
\hline \hline & & 3-Months Cummulative PT & 3-Months Cummulative PT \\
\hline 3 -Digit Naics & Naics Description & Rate for Yuan Exchange Rate & Rate for RWO Exchange Rate \\
\hline 311 & Food Manufacturing & 3.344 & 0.650 \\
\hline 312 & Beverage \& Tobacco & 0.22 & -0.015 \\
\hline 314 & Textile Product Mills & 0.229 & 0.009 \\
\hline 315 & Clothing & 0.031 & -0.109 \\
\hline 322 & Paper & 1.019 & 0.127 \\
\hline 325 & Chemicals & 1.842 & -0.046 \\
\hline 326 & Plastics \& Rubber & 1.203 & 0.138 \\
\hline 327 & Mineral Products & 0.449 & 1.534 \\
\hline 331 & Primary Metals & 1.756 & 0.003 \\
\hline 333 & Fabricated Metals & 0.813 & 0.205 \\
\hline 334 & Machinery & 0.502 & 0.041 \\
\hline 335 & Computers \& Electronic & 0.281 & -0.080 \\
\hline 336 & Transportation Equipment & 0.418 & 0.000 \\
\hline 339 & Misc. Manufacturing & 0.221 & 0.107 \\
\hline Average: & & 0.216 & $\mathbf{0 . 1 7 4}$ \\
\hline
\end{tabular}

\begin{tabular}{|c|c|c|c|c|c|c|c|c|c|c|}
\hline & (1) & (2) & (3) & (4) & (5) & (6) & (7) & (8) & (9) & (10) \\
\hline & \multicolumn{2}{|c|}{ 1-Month Horizon } & \multicolumn{2}{|c|}{ 3-Months Horizon } & \multicolumn{3}{|c|}{ (5)-(6) 6-Months Horizon } & \multicolumn{3}{|c|}{1 year Horizon } \\
\hline & OLS & $2 S L S$ & OLS (3 months) & $2 S L S$ (3 months) & $O L S$ & SLS (only contem & Iso lags are instru & $O L S$ & SLS (only contem & lso lags are instru \\
\hline & \multicolumn{10}{|c|}{ Dependent Variable is the 1-Month ((1)-(2)) or 3-Months $((3)-((10)))$ Change in the US PPI at the Naics 5 or 6 Digit Level } \\
\hline \multicolumn{11}{|c|}{ Independet Vars: Monthly Changes in US Import PPI Index (Naics 5 Digit Level } \\
\hline 1 Month Change & 0.2962 & 0.912 & & & & & & & & \\
\hline (bold indicates 2SLS coefficient) & {$[0.0115]^{* *}$} & {$[0.1503]^{* *}$} & & & & & & & & \\
\hline Cum. 3-Months Change & & & 0.5182 & 0.691 & 0.4961 & 0.6351 & 0.4196 & 0.4837 & 0.6095 & 0.588 \\
\hline (bold indicates 2SLS coefficient) & & & {$[0.0106]^{* *}$} & {$[0.0580]^{* *}$} & {$[0.0111]^{* *}$} & {$[0.0613]^{* *}$} & {$[0.0767]^{* *}$} & {$[0.0133]^{* *}$} & {$[0.0577]^{* *}$} & {$[0.1238]^{* *}$} \\
\hline Lag 3 of Cum. 3-Months Change & & & & & 0.1194 & 0.1047 & 0.3665 & 0.1249 & 0.0944 & -0.1554 \\
\hline (bold indicates 2SLS coefficient) & & & & & {$[0.0109]^{* *}$} & {$[0.0128]^{* *}$} & {$[0.0716]^{* *}$} & {$[0.0136]^{* *}$} & {$[0.0194]^{* *}$} & [0.2248] \\
\hline \multirow[t]{2}{*}{ Lag 6 of Cum. 3-Months Change } & & & & & & & & -0.0001 & 0.0259 & 0.6779 \\
\hline & & & & & & & & [0.0134] & {$[0.0178]$} & {$[0.3081]^{*}$} \\
\hline \multirow[t]{2}{*}{ Lag 9 of Cum. 3-Months Change } & & & & & & & & 0.0464 & 0.068 & -0.1556 \\
\hline & & & & & & & & {$[0.0138]^{* *}$} & {$[0.0169]^{* *}$} & {$[0.1893]$} \\
\hline \multicolumn{11}{|c|}{ Information On the First Stage of the 2SLS Estimations (Instruments are 1 Month Change of Ln(USD/Yuan) in (2), and Cumulated changes in (6), (7), (9), (10), and (12)) } \\
\hline \multicolumn{2}{|c|}{ P-value Assoc. w. Anderson canon. cor. LR statisti } & 0.000 & & 0.000 & & 0.000 & 0.000 & & 0.000 & 0.0022 \\
\hline Cragg-Donald F Statistic & & 44.932 & & 163.676 & & 146.376 & 146.376 & & 202.095 & 2.339 \\
\hline 10\% Stock-Yogo Critical Value & & 16.38 & & 16.38 & & & 7.03 & & 16.38 & na \\
\hline Observations & 4844 & 4844 & 4624 & 4624 & 4293 & 4293 & 4293 & 3631 & 3621 & 3621 \\
\hline Number of Groups & 110 & 110 & 110 & 110 & 110 & 110 & 110 & 110 & 100 & 100 \\
\hline R-squared (OLS) & 0.13 & & 0.35 & & 0.35 & & & 0.34 & & \\
\hline \multicolumn{5}{|c|}{ Standard errors in brackets; * significant at $5 \% ; * *$ significant at $1 \%$} & & & & & & \\
\hline
\end{tabular}


Table 4 - Autoregression and Long Run Pass Through of Import Prices Into Producers Prices: OLS and 2S LS Estimations

\begin{tabular}{|c|c|c|c|c|c|c|c|c|}
\hline & \multicolumn{2}{|c|}{$3 m P T, 12 m A R$} & \multicolumn{2}{|c|}{$6 \mathrm{mPT}, 12 \mathrm{mAR}$} & \multicolumn{2}{|c|}{$6 m P T, 24 m A R$} & \multicolumn{2}{|c|}{$12 \mathrm{mPT}, 24 \mathrm{~m} A R$} \\
\hline & OLS & $2 S L S$ & OLS & $2 S L S$ & OLS & $2 S L S$ & OLS & $2 S L S$ \\
\hline \multicolumn{9}{|c|}{ Dependent Variable is the 3-Months $((1)-(6)$ or 6-Months $((7)-(8))$ Change in the US PPI at the Naics 5 or 6 Digit Level } \\
\hline \multicolumn{9}{|c|}{ Independet Vars: Monthly Changes in US Import Price Index (Naics 5 Digit Level) } \\
\hline Cum. 3-Months Change & 0.4738 & 0.6661 & 0.4642 & 0.1235 & 0.4443 & 0.1144 & & \\
\hline (bold indicates 2SLS coefficient) & {$[0.0107]^{* *}$} & {$[0.0592]^{* *}$} & {$[0.0114]^{* *}$} & {$[0.1474]$} & {$[0.0114]^{* *}$} & {$[0.1367]$} & & \\
\hline \multirow[t]{2}{*}{ Cum. 6-Months Change } & & & & & & & 0.5057 & 0.2837 \\
\hline & & & & & & & {$[0.0112]^{* *}$} & {$[0.0400]^{* *}$} \\
\hline \multirow[t]{2}{*}{ Lag 6 of Cum. 6-Months Change } & & & & & & & 0.2682 & 0.5785 \\
\hline & & & & & & & {$[0.0146]^{* *}$} & {$[0.0528]^{* *}$} \\
\hline \multicolumn{9}{|l|}{ Lag 12 of Cum. 6-Months Change } \\
\hline & & & & & & & & \\
\hline
\end{tabular}

\begin{tabular}{|c|c|c|c|c|c|c|c|c|}
\hline Lag 3 of Cum. 3-Months Change & 0.0779 & 0.0691 & 0.0215 & -0.3951 & 0.0032 & -0.351 & & \\
\hline & {$[0.0120]^{* *}$} & {$[0.0127]^{* *}$} & {$[0.0151]$} & {$[0.1182]^{* *}$} & {$[0.0151]$} & {$[0.1039]^{* *}$} & & \\
\hline \multirow[t]{2}{*}{ Lag 6 of Cum. 3-Months Change } & -0.1109 & -0.1057 & -0.1273 & -0.1397 & -0.1574 & -0.1794 & & \\
\hline & {$[0.0109]^{* *}$} & {$[0.0114]^{* *}$} & {$[0.0120]^{* *}$} & {$[0.0171]^{* *}$} & {$[0.0124]^{* *}$} & {$[0.0180]^{* *}$} & & \\
\hline \multirow[t]{2}{*}{ Lag 9 of Cum. 3-Months Change } & -0.0927 & -0.0433 & -0.0917 & -0.2002 & -0.1241 & -0.2551 & & \\
\hline & {$[0.0107]^{* *}$} & {$[0.0186]^{*}$} & {$[0.0116]^{* *}$} & {$[0.0474]^{* *}$} & {$[0.0125]^{* *}$} & {$[0.0526]^{* *}$} & & \\
\hline \multirow[t]{2}{*}{ Lag 12 of Cum. 3-Months Change } & & & & & -0.0298 & -0.0184 & & \\
\hline & & & & & {$[0.0138]^{*}$} & {$[0.0187]$} & & \\
\hline \multirow[t]{2}{*}{ Lag 15 of Cum. 3-Months Change } & & & & & -0.1723 & -0.2724 & & \\
\hline & & & & & {$[0.0176]^{* *}$} & {$[0.0402]^{* *}$} & & \\
\hline \multirow[t]{2}{*}{ Lag 18 of Cum. 3-Months Change } & & & & & -0.0879 & -0.1694 & & \\
\hline & & & & & {$[0.0182]^{* *}$} & {$[0.0407]^{* *}$} & & \\
\hline \multirow[t]{2}{*}{ Lag 6 of Cum. 6-Months Change } & & & & & & & -0.365 & -0.6742 \\
\hline & & & & & & & {$[0.0169]^{* *}$} & {$[0.0472]^{* *}$} \\
\hline \multirow[t]{2}{*}{ Lag 12 of Cum. 6-Months Change } & & & & & & & -0.1809 & -0.2665 \\
\hline & & & & & & & {$[0.0155]^{* *}$} & {$[0.0217]^{* *}$} \\
\hline \multirow[t]{2}{*}{ Lag 18 of Cum. 6-Months Change } & & & & & & & -0.2671 & -0.3781 \\
\hline & & & & & & & {$[0.0192]^{* *}$} & {$[0.0269]^{* *}$} \\
\hline Trend & $\mathrm{y}$ & $\mathrm{y}$ & $\mathrm{y}$ & $\mathrm{y}$ & $\mathrm{y}$ & $\mathrm{y}$ & $\mathrm{y}$ & $\mathrm{y}$ \\
\hline Fixed Effects (by Sector9 & $\mathrm{y}$ & $\mathrm{y}$ & $\mathrm{y}$ & $\mathrm{y}$ & $\mathrm{y}$ & $\mathrm{y}$ & y & $\mathrm{y}$ \\
\hline
\end{tabular}

Information On the First Stage of the 2SLS Estimations (Instruments are 1 Month Change of Ln(USD/Yuan) in (2) and Cum. changes in (6), (7), (9), (10))

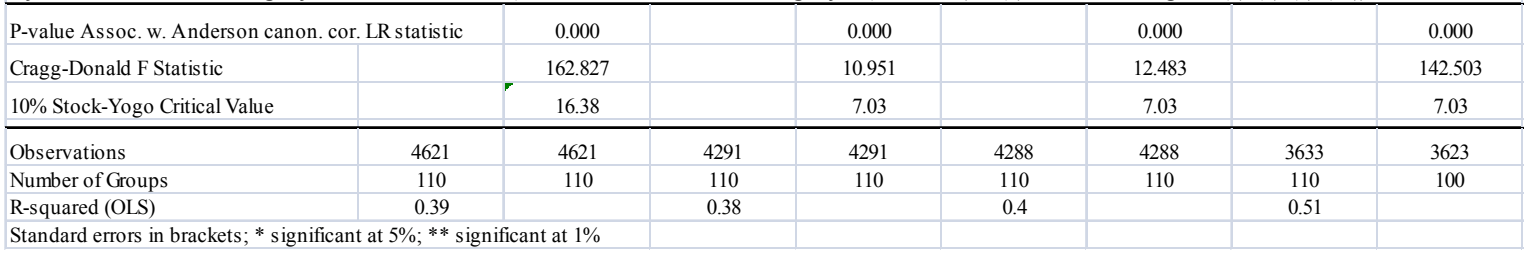


Table 5 - The Herogenous Impact of Exchange Rates on Producer Prices (Reduced Form Es timations)

\begin{tabular}{|l|c|c|c|c|c|c|}
\hline \hline & $(1)$ & $(2)$ & $(3)$ & $(4)$ & $(5)$ & $(6)$ \\
\hline
\end{tabular}

Panel A: 3 Month Changes - Dependent Variable is the 3-Months Change in the US Import PPI at the Naics 6 Digit Level

\begin{tabular}{|c|c|c|c|c|c|c|c|c|}
\hline Cum. 3-Months Change & 0.2397 & 0.7796 & 0.6454 & 0.3964 & 0.7331 & 0.233 & 0.4711 & 0.5461 \\
\hline & {$[0.0175]^{* *}$} & {$[0.0519]^{* *}$} & {$[0.0490]^{* *}$} & {$[0.0306]^{* *}$} & {$[0.0462]^{* *}$} & {$[0.0237]^{* *}$} & {$[0.0395]^{* *}$} & {$[0.0385]^{* *}$} \\
\hline
\end{tabular}

Panel B: 3 Month Changes \& Adding a Lag - Dependent Variable is the 3-Months Change in the US Import PPI at the Naics 6 Digit Level

\begin{tabular}{|c|c|c|c|c|c|c|c|c|}
\hline \multirow[t]{2}{*}{ Cum. 3-Months Change } & 0.0743 & 0.4803 & 0.3945 & 0.1656 & 0.412 & 0.1033 & 0.2309 & 0.3222 \\
\hline & {$[0.0193]^{* *}$} & {$[0.0606]^{* *}$} & {$[0.0555]^{* *}$} & {$[0.0368]^{* *}$} & {$[0.0532]^{* *}$} & {$[0.0285]^{* *}$} & {$[0.0428]^{* *}$} & {$[0.0476]^{* *}$} \\
\hline \multirow[t]{2}{*}{ Lag 3 of Cum. 3-Months Change } & 0.3077 & 0.5613 & 0.4767 & 0.4157 & 0.6021 & 0.2343 & 0.439 & 0.4282 \\
\hline & {$[0.0241]^{* *}$} & {$[0.0642]^{* *}$} & {$[0.0589]^{* *}$} & {$[0.0408]^{* *}$} & {$[0.0579]^{* *}$} & {$[0.0283]^{* *}$} & {$[0.0490]^{* *}$} & {$[0.0482]^{* *}$} \\
\hline
\end{tabular}

Panel C: 6 Month Changes - Dependent Variable is the 6-Months Change in the US Import PPI at the Naics 5 Digit Level

\begin{tabular}{|c|c|c|c|c|c|c|c|c|}
\hline Cum. 3-Months Change & 0.2787 & 0.9097 & 0.7567 & 0.4696 & 0.8658 & 0.2599 & 0.5528 & 0.6329 \\
\hline & {$[0.0163]^{* *}$} & {$[0.0496]^{* *}$} & {$[0.0474]^{* *}$} & {$[0.0288]^{* *}$} & {$[0.0446]^{* *}$} & {$[0.0205]^{* *}$} & {$[0.0393]^{* *}$} & {$[0.0350]^{* *}$} \\
\hline
\end{tabular}

Panel D: 6 Month Changes \& Adding a Lag - Dependent Variable is the 6-Months Change in the US Import PPI at the Naics 6 Digit Level

\begin{tabular}{|c|c|c|c|c|c|c|c|c|}
\hline \multirow[t]{2}{*}{ Cum. 6-Months Change } & 0.2076 & 0.882 & 0.7667 & 0.3587 & 0.8292 & 0.1979 & 0.493 & 0.5943 \\
\hline & {$[0.0178]^{* *}$} & {$[0.0575]^{* *}$} & {$[0.0556]^{* *}$} & {$[0.0320]^{* *}$} & {$[0.0514]^{* *}$} & {$[0.0241]^{* *}$} & {$[0.0442]^{* *}$} & {$[0.0418] * *$} \\
\hline \multirow[t]{2}{*}{ Lag 6 of Cum. 3-Months Change } & 0.2668 & 0.1112 & 0.0519 & 0.3296 & 0.1679 & 0.2146 & 0.2228 & 0.1549 \\
\hline & {$[0.0201]^{* *}$} & {$[0.0684]$} & {$[0.0664]$} & {$[0.0358]^{* *}$} & {$[0.0610]^{* *}$} & {$[0.0279]^{* *}$} & {$[0.0509]^{* *}$} & {$[0.0500]^{* *}$} \\
\hline Fixed Effects (All Panels) & $\mathrm{y}$ & $\mathrm{y}$ & $\mathrm{y}$ & $\mathrm{y}$ & $\mathrm{y}$ & $\mathrm{y}$ & $\mathrm{y}$ & $\mathrm{y}$ \\
\hline Trend (All Panels) & $\mathrm{y}$ & $\mathrm{y}$ & y & $\mathrm{y}$ & $\mathrm{y}$ & $\mathrm{y}$ & $\mathrm{y}$ & $\mathrm{y}$ \\
\hline Observations (Panel A) & 11077 & 11005 & 10285 & 9951 & 12065 & 9564 & 11028 & 11054 \\
\hline Number of Groups (All Panels) & 159 & 161 & 154 & 148 & 176 & 137 & 158 & 162 \\
\hline R-squared (Panel A) & 0.03 & 0.03 & 0.03 & 0.03 & 0.04 & 0.01 & 0.02 & 0.03 \\
\hline \multicolumn{9}{|c|}{ Standard errors in brackets; $*$ significant at $5 \% ; * *$ significant at $1 \%$} \\
\hline \multicolumn{2}{|c|}{ All estimaitons include fixed effects and a trend } & & & & & & & \\
\hline
\end{tabular}


Table 6 - Herogenous Pass Through Rates: 2SLS Es timates

\begin{tabular}{|c|c|c|c|c|c|c|c|c|}
\hline & (1) & (2) & (3) & (4) & (5) & (6) & (7) & (8) \\
\hline & \multicolumn{2}{|c|}{ Labor Intensity } & \multicolumn{2}{|c|}{ Demand Elasticity } & \multicolumn{2}{|c|}{ Input Intensity } & \multicolumn{2}{|c|}{ Import Penetration w/o China } \\
\hline & Above Median & Below Median & Above Median & Below Median & none & at least some & Above Median & Below Median \\
\hline \multicolumn{9}{|c|}{ Panel C: OLS Coefficients Dependent Variable is the 3 Months Change in the US PPI at the Naics 5 or 6 Digit Level } \\
\hline Monthly Ch. Import Price & 0.2397 & 0.7796 & 0.5976 & 0.3964 & 0.7331 & 0.233 & 0.4711 & 0.5461 \\
\hline (not instrumented) & {$[0.0175]^{* *}$} & {$[0.0519]^{* *}$} & {$[0.0440]^{* *}$} & {$[0.0306]^{* *}$} & {$[0.0462]^{* *}$} & {$[0.0237]^{* *}$} & {$[0.0395]^{* *}$} & {$[0.0385]^{* *}$} \\
\hline \multicolumn{9}{|c|}{ Panel B: 2 SLS Second Stage: Dependent Variable is the 3 Months Change in the US PPI at the Naics 5 or 6 Digit Level } \\
\hline Monthly Ch. Import Price & 0.7064 & 0.683 & 0.6815 & 0.7155 & 0.7551 & 0.5952 & 0.7289 & 0.6635 \\
\hline (instrumented) & {$[0.0970]^{* *}$} & {$[0.0667]^{* *}$} & {$[0.0955]^{* *}$} & {$[0.0680]^{* *}$} & {$[0.0668]^{* *}$} & {$[0.0949]^{* *}$} & {$[0.0879]^{* *}$} & {$[0.0701]^{* *}$} \\
\hline \multicolumn{9}{|c|}{ Panel A: Dependent Variable is the 3 Months Change in the US Import PPI at the Naics 5 Digit Level } \\
\hline \multirow[t]{2}{*}{ Monthly Ch. In(USD per Yuan) } & 0.3685 & 1.0139 & 0.4756 & 0.7863 & 0.9678 & 0.3557 & 0.4632 & 0.8524 \\
\hline & {$[0.0352]^{* *}$} & {$[0.0941]^{* *}$} & {$[0.0681]^{* *}$} & {$[0.0556]^{* *}$} & {$[0.0904]^{* *}$} & {$[0.0334]^{* *}$} & {$[0.0361]^{* *}$} & {$[0.0899]^{* *}$} \\
\hline \multicolumn{9}{|c|}{ Information On the First Stage of the 2SLS Estimations } \\
\hline P-value Assoc. w. Anderson cano & 0.00000 & 0.00000 & 0.00000 & 0.00000 & 0.00000 & 0.00000 & 0.00000 & 0.00000 \\
\hline Cragg-Donald F Statistic & 122.327 & 84.962 & 35.268 & 214.437 & 84.909 & 125.294 & 78.866 & 88.412 \\
\hline $10 \%$ Stock-Yogo Critical Value & 16.38 & 16.38 & 16.38 & 16.38 & 16.38 & 16.38 & 16.38 & 16.38 \\
\hline Observations & 2730 & 1894 & 2462 & 2162 & 2010 & 2558 & 2654 & 1970 \\
\hline Number of Groups & 63 & 47 & 99 & 53 & 50 & 58 & 63 & 47 \\
\hline R-squared (1st Stage) & 0.07 & 0.05 & 0.02 & 0.11 & 0.05 & 0.08 & 0.04 & 0.07 \\
\hline \multicolumn{5}{|c|}{ Standard errors in brackets; $*$ significant at $5 \% ; * *$ significant at $1 \%$} & & & & \\
\hline
\end{tabular}


Table 7 - 2SLS Estimates Utilizing the Interaction of Sector Characteristics and Exchange Rates

\begin{tabular}{|c|c|c|c|c|c|c|c|c|}
\hline & (1) & (2) & (3) & (4) & (5) & (6) & (7) & (8) \\
\hline & \multicolumn{2}{|c|}{ Labor Intensity } & \multicolumn{2}{|c|}{ Demand Elasticity } & \multicolumn{2}{|c|}{ Input Intensity } & \multicolumn{2}{|c|}{ Import Penetration w/o China } \\
\hline & Including & Adding Time & Including & Adding Time & Including & Adding Time & Including & Adding Time \\
\hline & Interaction & Dummies & Interaction & Dummies & Interaction & Dummies & Interaction & Dummies \\
\hline \multicolumn{9}{|c|}{ Panel B: 2 SLS Second Stage: Dependent Variable is the 3-Months Change in the US PPI at the Naics 5 or 6 Digit Level } \\
\hline Instrumented 3-Months Ch. & 0.7098 & 0.756 & 0.7199 & 0.6507 & 0.704 & 0.7146 & 0.6886 & 0.6748 \\
\hline Import Price & {$[0.0554]^{* *}$} & {$[0.0924]^{* *}$} & {$[0.0575]^{* *}$} & {$[0.3138]^{*}$} & {$[0.0560]^{* *}$} & {$[0.2077]^{* *}$} & {$[0.0548]^{* *}$} & {$[0.1821]^{* *}$} \\
\hline \multicolumn{9}{|c|}{ Panel A: Dependent Variable is the 3-Months Change in the US Import PPI at the Naics 5 Digit Level } \\
\hline \multirow[t]{2}{*}{ 3-Months Ch.ln(USD per Yuan) } & 0.6698 & & 0.6338 & & 0.6555 & & 0.6603 & \\
\hline & {$[0.0935]^{* *}$} & & {$[0.0984]^{* *}$} & & {$[0.1046]^{* *}$} & & {$[0.0993]^{* *}$} & \\
\hline \multirow[t]{2}{*}{$3 m$ Ch. Exr * Labor Intensity } & -0.4419 & -0.4405 & & & & & & \\
\hline & {$[0.1218]^{* *}$} & {$[0.1226]^{* *}$} & & & & & & \\
\hline \multirow[t]{2}{*}{$3 m$ Ch. Exr $*$ Demand Elasticity } & & & -0.0975 & -0.1051 & & & & \\
\hline & & & {$[0.0936]$} & {$[0.0940]$} & & & & \\
\hline \multirow[t]{2}{*}{$3 m$ Ch. Exr $*$ Input Intensity } & & & & & -0.1503 & -0.1494 & & \\
\hline & & & & & {$[0.0640]^{*}$} & {$[0.0641]^{*}$} & & \\
\hline \multirow[t]{2}{*}{$3 m$ Ch. Exr * Row Trade Openess } & & & & & & & -0.2277 & -0.2269 \\
\hline & & & & & & & {$[0.0892]^{*}$} & {$[0.0895]^{*}$} \\
\hline \multicolumn{9}{|c|}{ Additional First-Stage Information } \\
\hline \multicolumn{9}{|l|}{ Anderson canon. cor. LR statistic } \\
\hline P-value & $<0.0001$ & $<0.0001$ & $<0.0001$ & 0.09190 & $<0.0001$ & 0.00030 & $<0.0001$ & $<0.0001$ \\
\hline \multicolumn{9}{|l|}{ Cragg-Donald F Test } \\
\hline $\begin{array}{r}\text { Statistic } \\
\end{array}$ & 117.243 & 72.373 & 76.023 & 5.53 & 85.376 & 12.877 & 95.985 & 28.898 \\
\hline $10 \%$ Stock-Yogo Critical Value & 19.93 & 16.38 & 19.93 & 16.38 & 19.93 & 16.38 & 19.93 & 16.38 \\
\hline $20 \%$ Stock-Yogo Critical Value & 8.75 & 6.66 & 8.75 & 6.66 & 8.75 & 6.66 & 8.75 & 6.66 \\
\hline \multicolumn{9}{|l|}{ Hansen J-Test of Overidentification } \\
\hline P-value & 0.4603 & na & 0.8761 & na & 0.9701 & na & 0.9298 & na \\
\hline \multicolumn{9}{|c|}{ Model Information (Variables Included in Both Second and First Stage) } \\
\hline Trend & $\mathrm{y}$ & $\mathrm{n}$ & $\mathrm{y}$ & $\mathrm{n}$ & $\mathrm{y}$ & $\mathrm{n}$ & y & $\mathrm{n}$ \\
\hline Time Dummies & $\mathrm{n}$ & y & $\mathrm{n}$ & $\mathrm{y}$ & $\mathrm{n}$ & $\mathrm{y}$ & $\mathrm{n}$ & $\mathrm{y}$ \\
\hline Fixed Effects By Sector & y & y & $\mathrm{y}$ & $\mathrm{y}$ & y & y & y & y \\
\hline Observations & 4624 & 4624 & 4304 & 4304 & 4568 & 4568 & 4624 & 4624 \\
\hline Number of Groups & 110 & 110 & 105 & 105 & 108 & 108 & 110 & 110 \\
\hline R-squared (1st Stage) & 0.06 & 0.13 & 0.05 & 0.12 & 0.05 & 0.12 & 0.05 & 0.12 \\
\hline Standard errors in brackets; ${ }^{*}$ significar & t at $5 \% ; * *$ si & icant at $1 \%$ & & & & & & \\
\hline
\end{tabular}


Table 8 - 2SLS Estimates Utilizing the Four Interaction of Sector Characteristics and Exchange Rate Changes

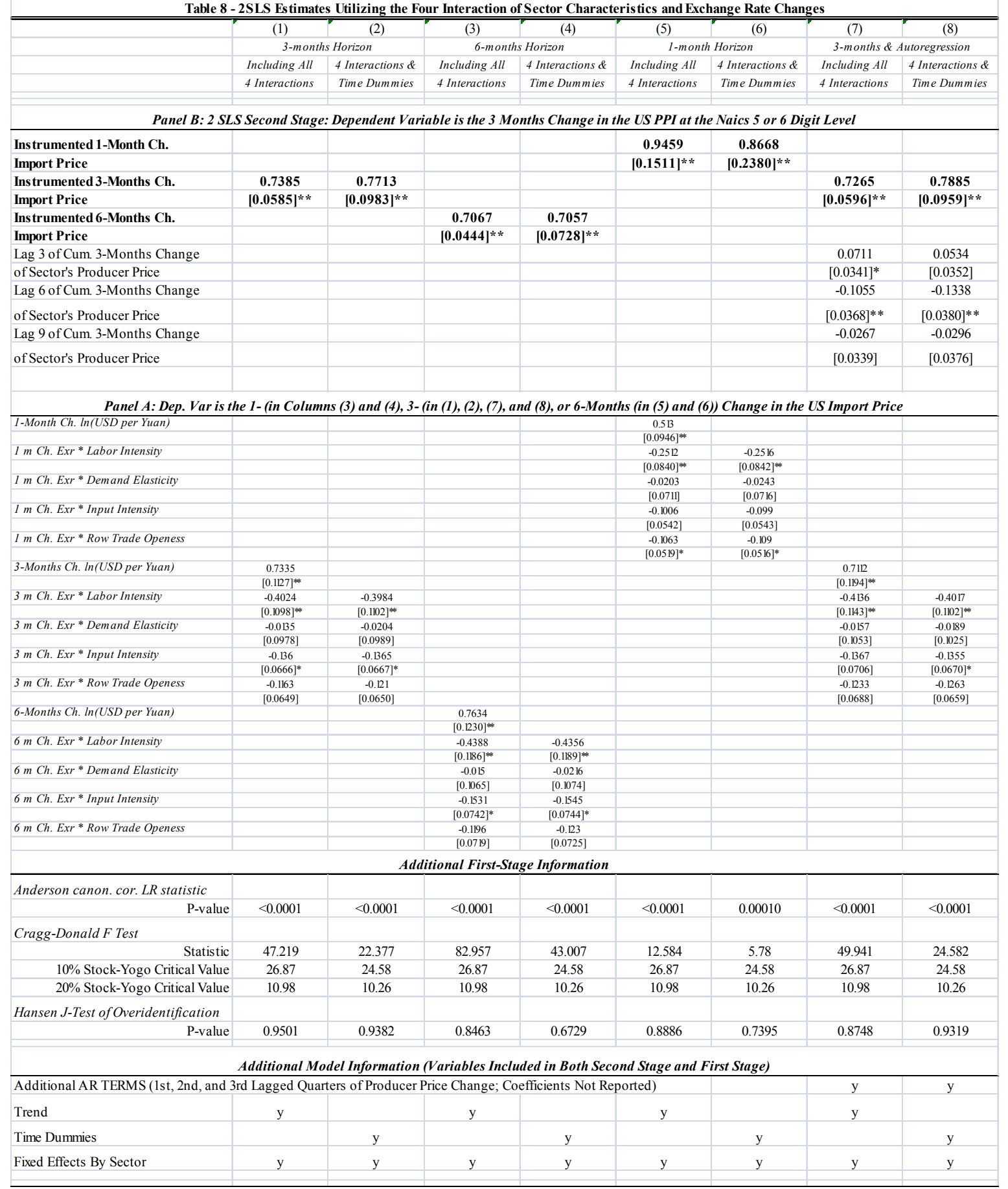




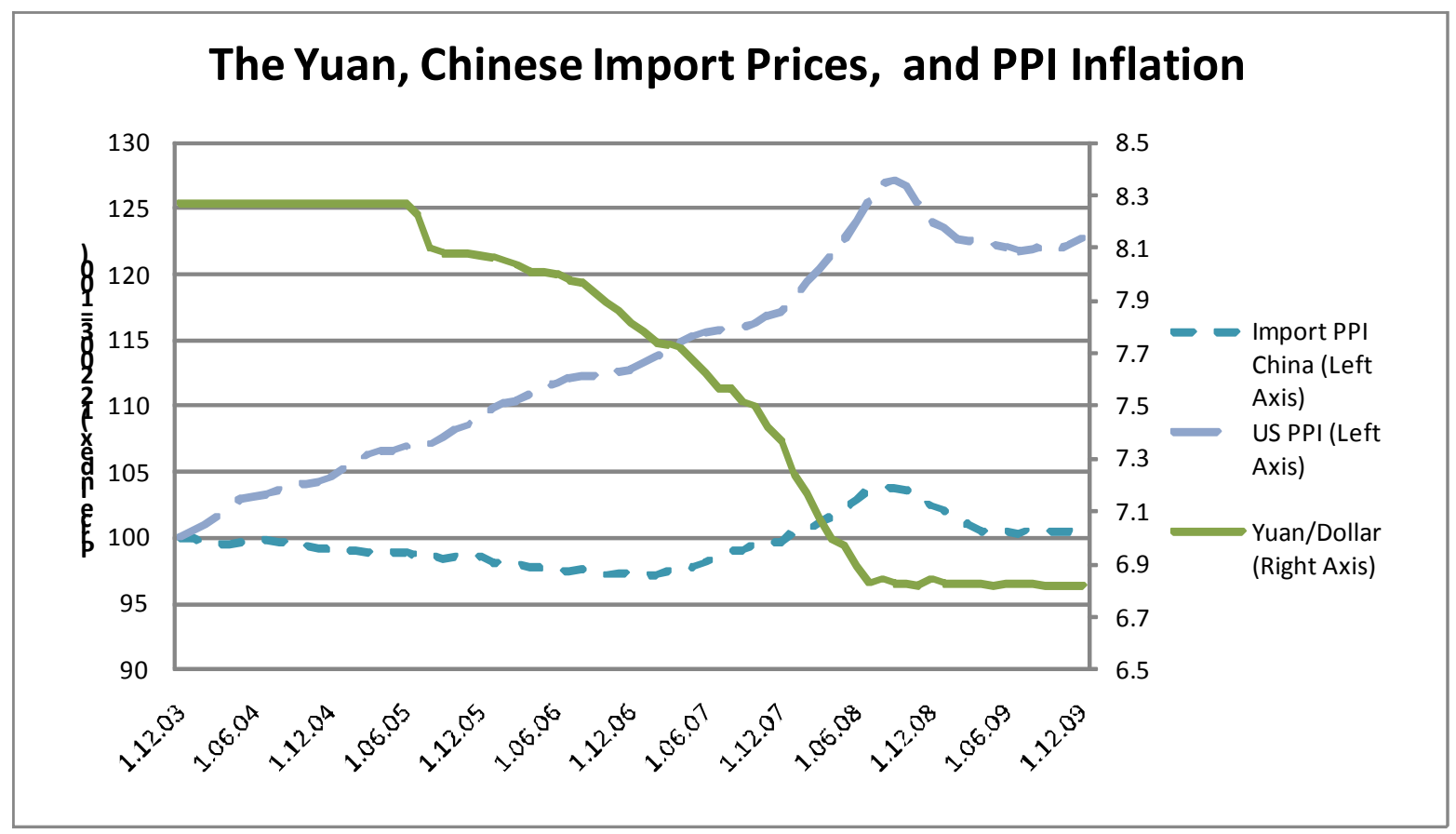

Figure 1

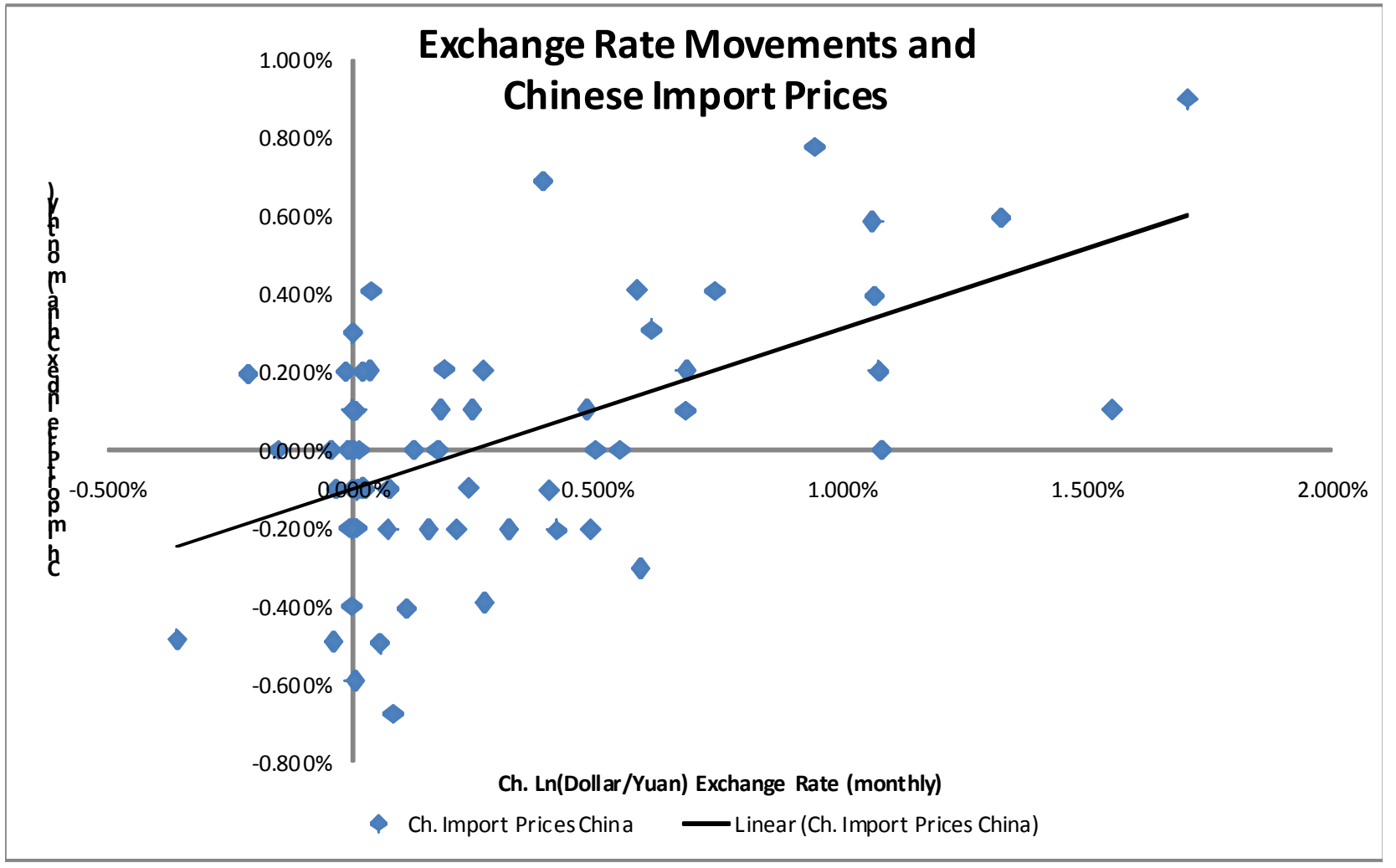

Figure 2 


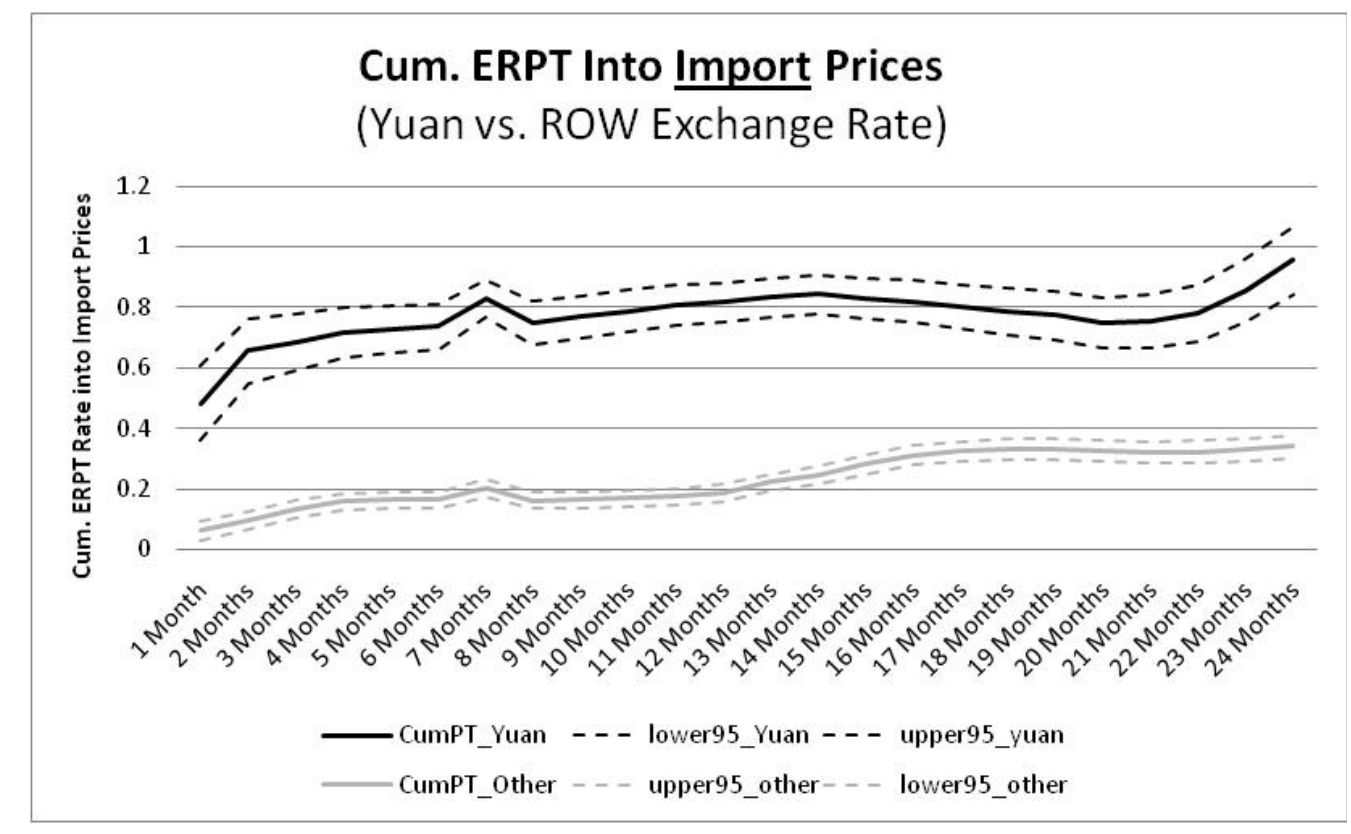

Figure 3

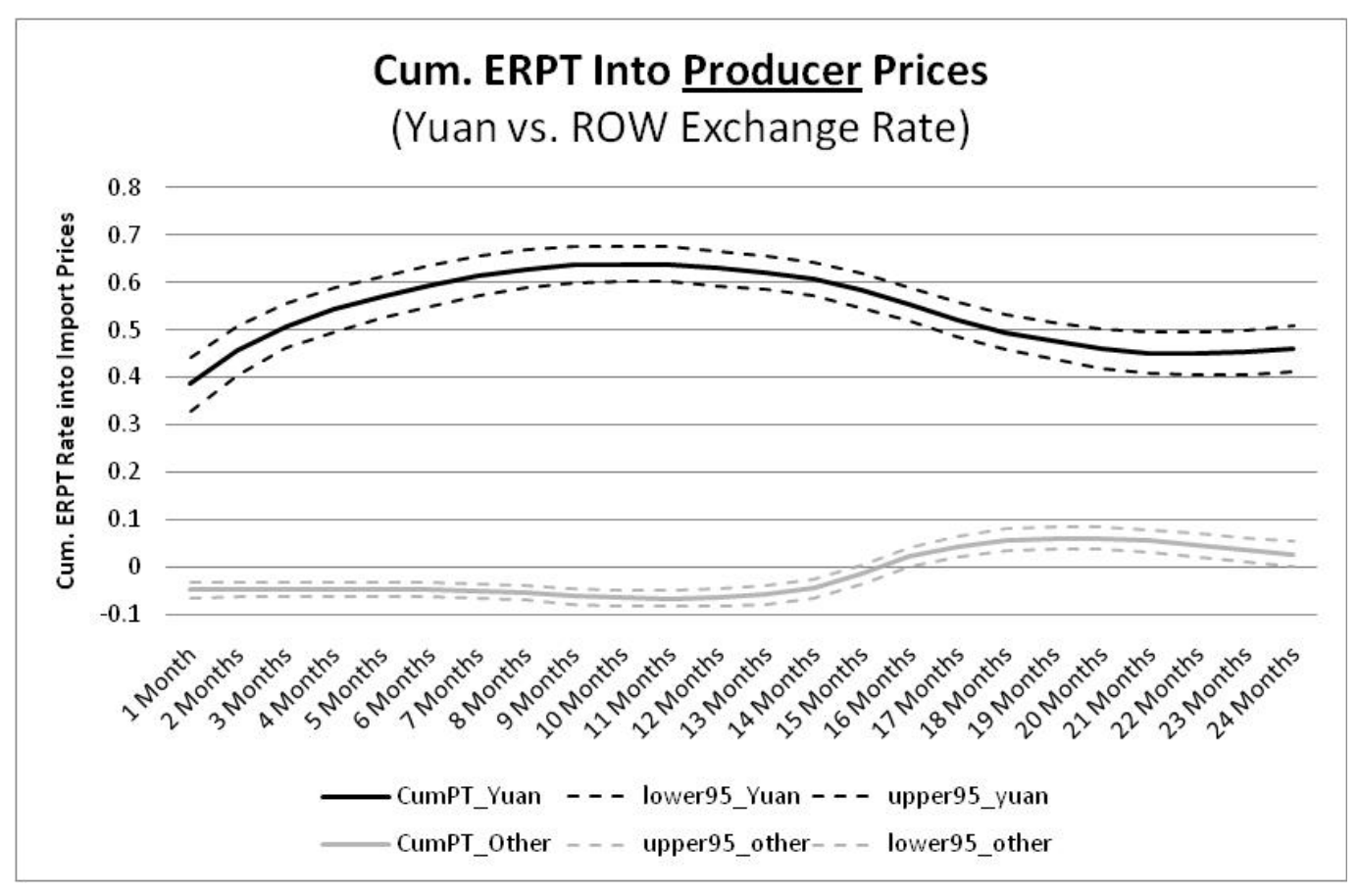

Figure 4 


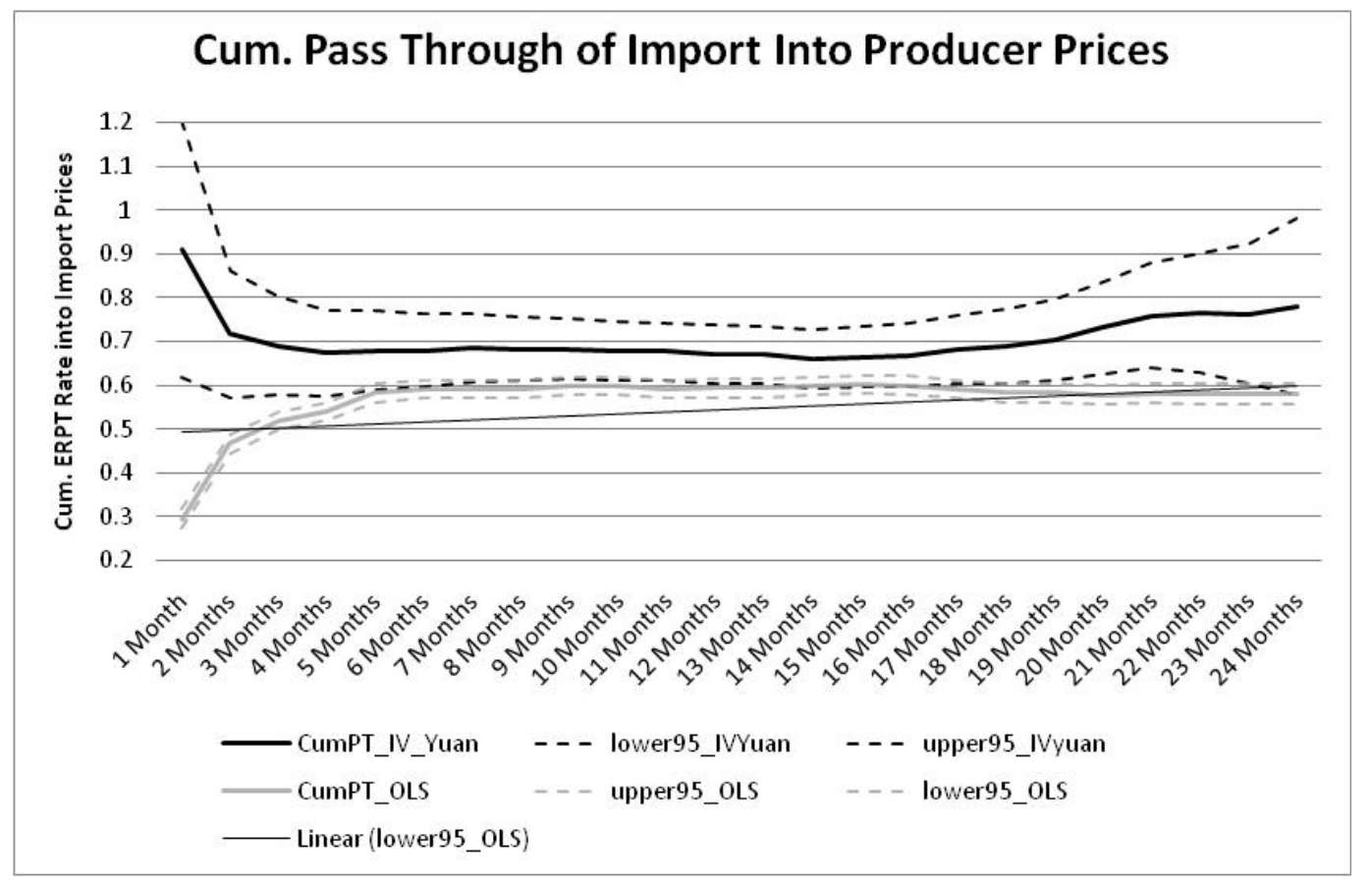

Figure 5

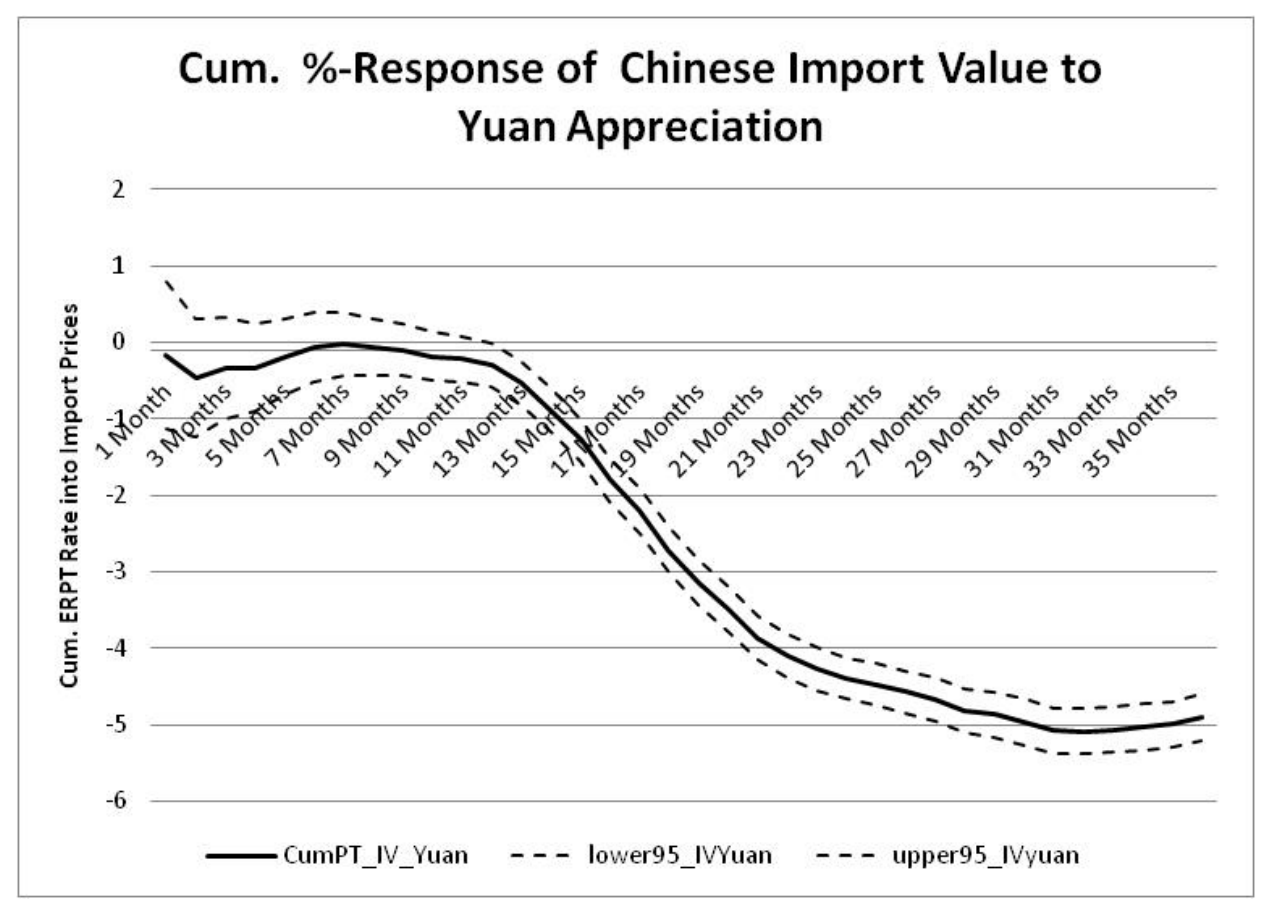

Figure 6 


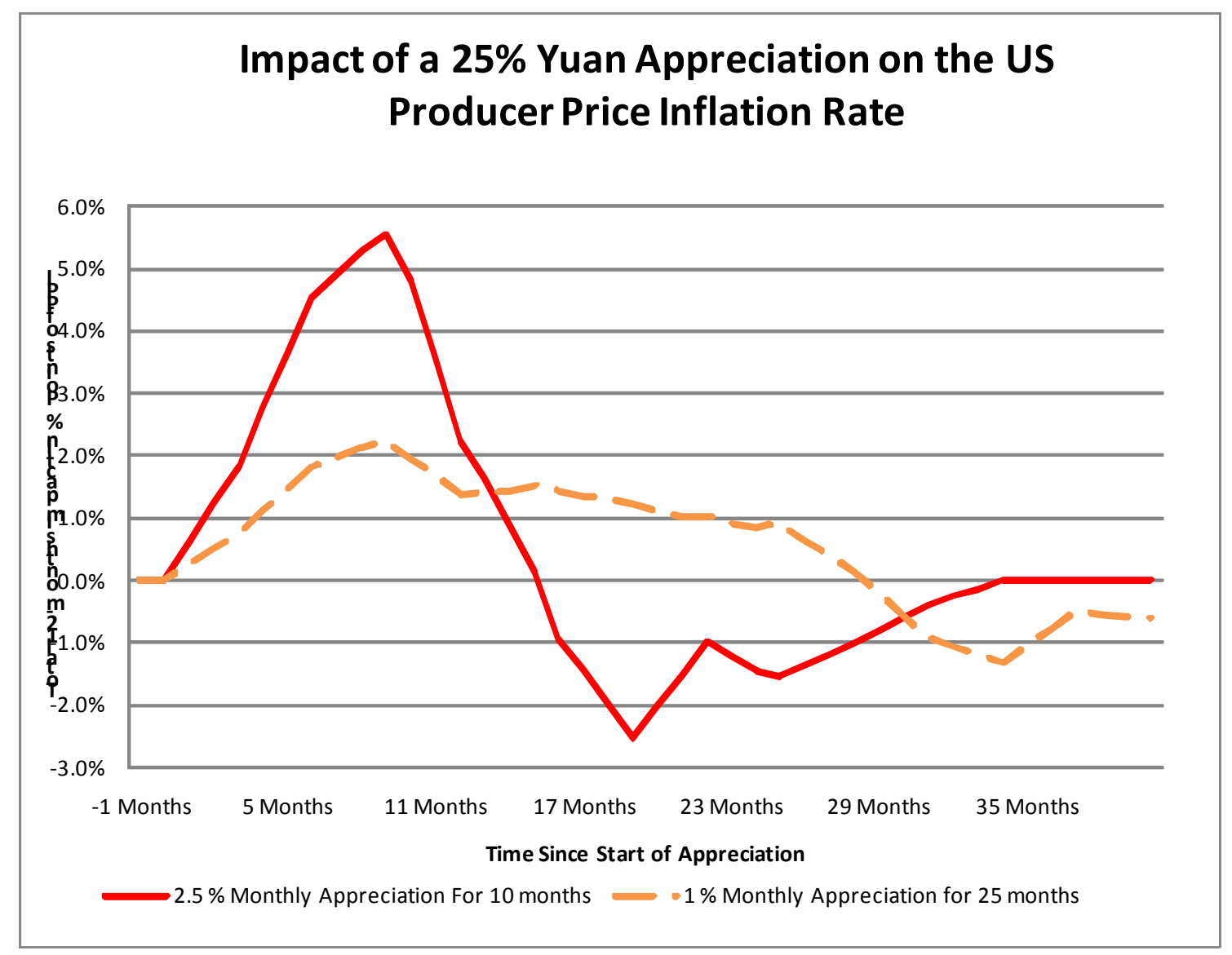

Figure 7 


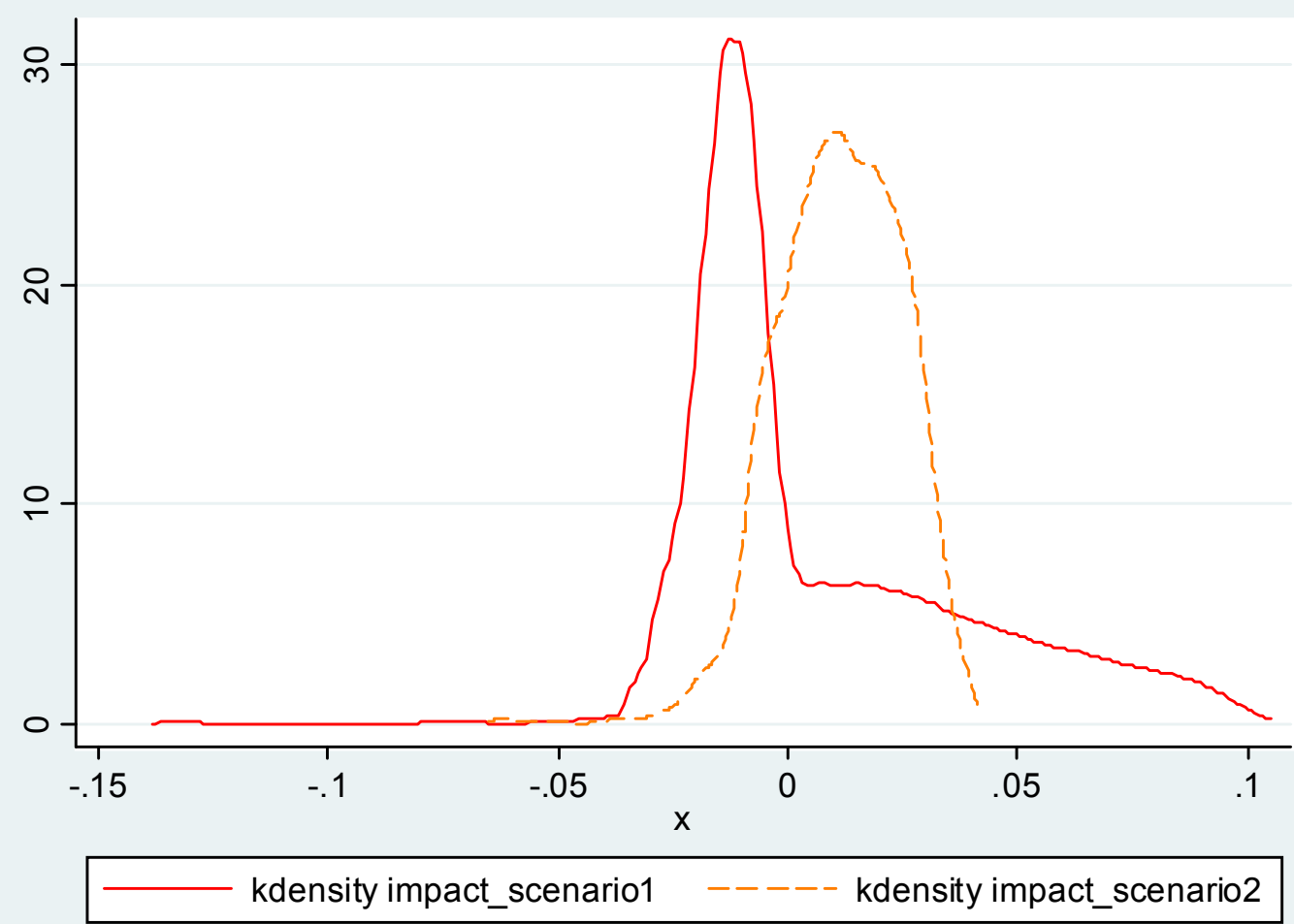

Figure 8 